University of Wollongong

Research Online

$1-1-2017$

\title{
The effects of maternal antidepressant use on offspring behaviour and brain development: Implications for risk of neurodevelopmental disorders
}

\author{
Samuel Millard \\ University of Wollongong, sjlm995@uowmail.edu.au \\ Katrina Weston-Green \\ University of Wollongong, kweston@uow.edu.au \\ Kelly A. Newell \\ University of Wollongong, knewell@uow.edu.au
}

Follow this and additional works at: https://ro.uow.edu.au/ihmri

Part of the Medicine and Health Sciences Commons

\section{Recommended Citation}

Millard, Samuel; Weston-Green, Katrina; and Newell, Kelly A., "The effects of maternal antidepressant use on offspring behaviour and brain development: Implications for risk of neurodevelopmental disorders" (2017). Illawarra Health and Medical Research Institute. 1121. 


\title{
The effects of maternal antidepressant use on offspring behaviour and brain development: Implications for risk of neurodevelopmental disorders
}

\author{
Abstract \\ Approximately $10 \%$ of pregnant women are prescribed antidepressant drugs (ADDs), with selective \\ serotonin reuptake inhibitors (SSRIs) the most widely prescribed. SSRIs bind to the serotonin transporter \\ (SERT), blocking the reabsorption of serotonin by the presynaptic neuron and increasing serotonin levels \\ in the synaptic cleft. The serotonergic system regulates a range of brain development processes \\ including neuronal proliferation, migration, differentiation and synaptogenesis. Given the presence of \\ SERT in early brain development, coupled with the ability of SSRIs to cross the placenta and also enter \\ breast milk, concerns have been raised regarding the effects of SSRI exposure on the developing foetus \\ and newborns. In this review, we evaluate preclinical and clinical studies that have examined the effects \\ of maternal SSRI exposure and the risk for altered neurodevelopment and associated behaviours in \\ offspring. While the current body of evidence suggests that maternal SSRI treatment may cause \\ perturbations to the neurobiology, behaviour and ultimately risk for neurodevelopmental disorders in \\ exposed offspring, conflicting findings do exist and the evidence is not conclusive. However, given the \\ increasing incidence of depression and number of women prescribed ADDs during pregnancy, further \\ investigation into this area is warranted.

\section{Disciplines} \\ Medicine and Health Sciences

\section{Publication Details} \\ Millard, S. J., Weston-Green, K. \& Newell, K. A. (2017). The effects of maternal antidepressant use on \\ offspring behaviour and brain development: Implications for risk of neurodevelopmental disorders. \\ Neuroscience and Biobehavioral Reviews, 80 743-765.
}


The effects of maternal antidepressant use on offspring behaviour and brain development: implications for risk of neurodevelopmental disorders

\section{Authors:}

Samuel J. Millard ${ }^{a, b}$, Katrina Weston-Green ${ }^{a, b}$, Kelly A. Newell ${ }^{a, b *}$

\section{Affiliations:}

a School of Medicine, Faculty of Science, Medicine and Health, University of Wollongong, Wollongong, New South Wales 2522 Australia

${ }^{b}$ Illawarra Health and Medical Research Institute, Wollongong, New South Wales 2522 Australia

\section{Email Addresses}

sjlm995@uow.edu.au (S.J.M), katrina_green@uow.edu.au (K.W.G), knewell@uow.edu.au (K.A.N)*

\section{*Corresponding Author}

Dr Kelly A. Newell, School of Medicine, Faculty of Science, Medicine and Health, University of Wollongong, Wollongong, New South Wales 2522 Australia

Email: knewell@uow.edu.au Tel: +61242215743

\section{Abstract}

Approximately $10 \%$ of pregnant women are prescribed antidepressant drugs (ADDs), with selective serotonin reuptake inhibitors (SSRIS) the most widely prescribed. SSRIs bind to the serotonin transporter (SERT), blocking the reabsorption of serotonin by the presynaptic neuron and increasing serotonin levels in the synaptic cleft. The serotonergic system regulates a range of brain development processes including neuronal proliferation, migration, differentiation and synaptogenesis. Given the presence of SERT in early brain development, coupled with the ability of SSRIs to cross the placenta and also enter breast milk, concerns have been raised regarding the effects of SSRI exposure on the developing foetus and newborns. In this review, we evaluate preclinical and clinical studies that have examined the effects of maternal SSRI exposure and the risk for altered neurodevelopment and associated behaviours in offspring. While the current body of evidence suggests that maternal SSRI treatment may cause perturbations to the neurobiology, behaviour and ultimately risk for neurodevelopmental disorders in exposed offspring, conflicting findings 
do exist and the evidence is not conclusive. However given the increasing incidence of depression and number of women prescribed ADDs during pregnancy, further investigation into this area is warranted.

\section{Graphical Abstract:}

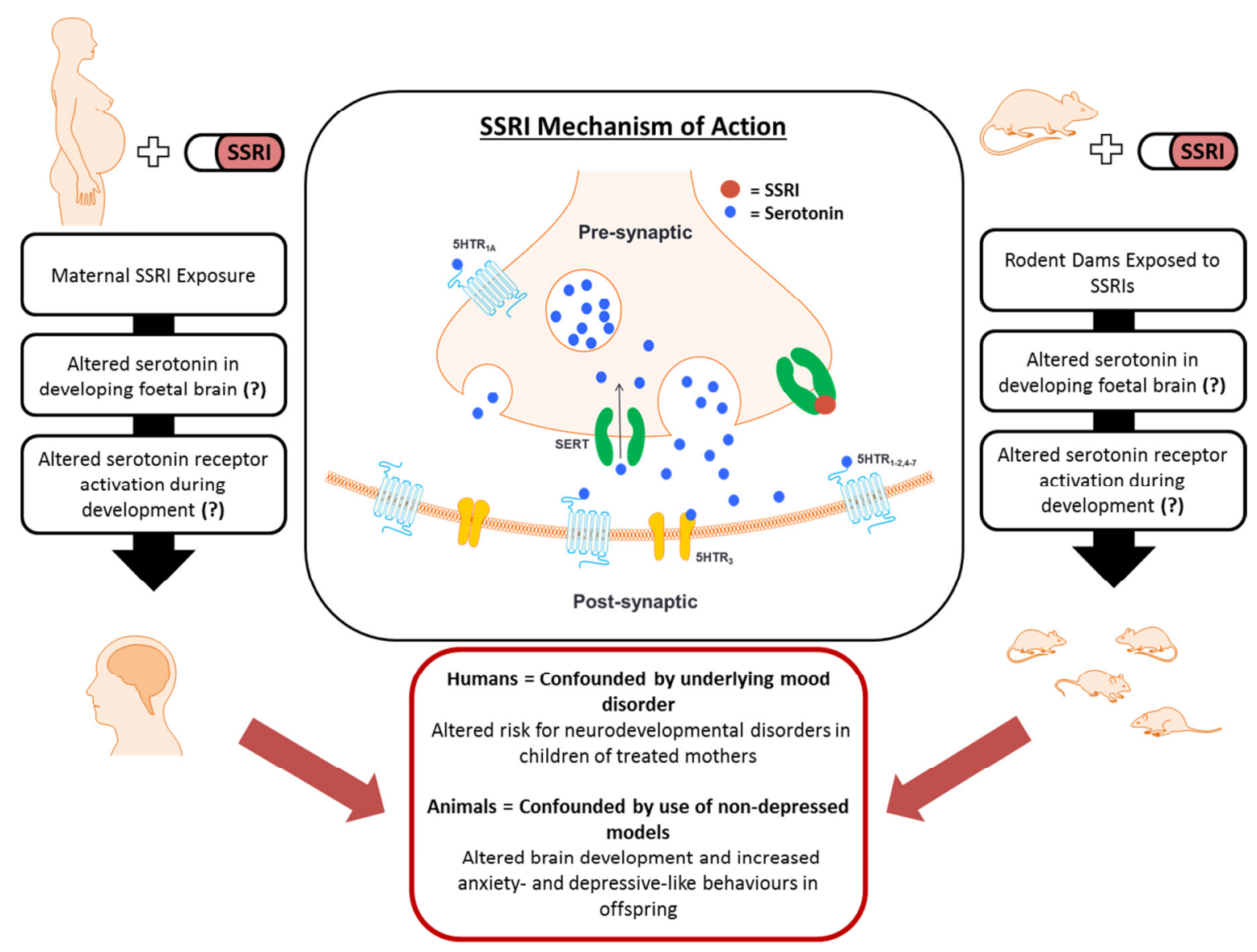

\section{Keywords:}

Serotonin; SSRI; Brain development; Neurodevelopmental Disorder; Rodent Model; Fluoxetine; Depression; Pregnancy 
1.1 Introduction. Antidepressant drugs (ADDs) are currently one of the most widely prescribed drug classes worldwide, administered to over $10 \%$ of the population for the treatment of clinical depression and anxiety-related disorders (Moore et al., 2009; Olfson and Marcus, 2009). Similarly, $8-10 \%$ of pregnant women are prescribed ADDs for the treatment of depression (Cooper et al., 2007; Huybrechts et al., 2013). With the overall incidence of depression significantly rising over the last several decades, this value may continue to increase (Huybrechts et al., 2013; Kessler, 2003). While various classes of ADDs exist, selective serotonin reuptake inhibitors (SSRIs) are the most widely prescribed to pregnant women (in 80\% of cases) (Huybrechts et al., 2013; Mitchell et al., 2011) and have been considered moderately safe for antenatal use (Oberlander et al., 2009). However, recent analyses indicate that maternal use of SSRIs, particularly paroxetine, is associated with greater risk of structural neuroteratogenic effects (Reefhuis et al., 2015). SSRIs, such as fluoxetine, sertraline, and citalopram (the most commonly prescribed SSRIs during pregnancy (Patil et al., 2011) bind to the serotonin transporter (SERT), blocking the reabsorption of serotonin by the presynaptic neuron and increasing serotonin levels in the synaptic cleft (Hiemke and Härtter, 2000) (Figure 1). While SSRIs cause acute elevations in serotonin concentrations, the antidepressant properties of SSRIs are largely thought to be elicited by downstream mechanisms, such as increases in brain derived neurotrophic factor (BDNF) and subsequent neurogenesis in the prefrontal cortex (PFC) and hippocampus (Martinowich and Lu, 2007). The serotonergic system and other downstream effectors, such as BDNF, are also critical for normal neurodevelopment. This raises concerns about exposure of the developing foetus and newborns to SSRIs as it has been shown that SSRIs administered during pregnancy cross the placenta (Heikkinen et al., 2002) and are excreted in breast milk (Hendrick et al., 2001; Kim et al., 2006). This concern is accentuated by studies demonstrating associations between abnormal neurodevelopment of the serotonergic system and several psychiatric and behavioural disorders, such as Autism Spectrum Disorder (ASD) (Hranilovic et al., 2007; Mulder et al., 2004; Schain and Freedman, 1961), AttentionDeficit Hyperactivity Disorder (ADHD) (Banerjee et al., 2006; Oades et al., 2002; Retz et al., 2008), anxiety and depression (Caspi et al., 2003; Olivier et al., 2011) and schizophrenia (Bleich et al., 1988; Ikeda et al., 2005). 


\subsection{Development of the Serotonergic System}

The serotonergic system plays an important role in early brain development and is critical to a range of processes, including neuronal proliferation, migration, differentiation and synaptogenesis (Vitalis and Parnavelas, 2003; Whitaker-Azmitia, 2001). Serotonergic neurons and receptors appear in the human brain by gestational week 5 (Figure 2); it is one of the earliest monoaminergic systems generated during development (Gaspar et al., 2003; Lambe et al., 2011; Sundström et al., 1993; Whitaker-Azmitia, 2001). By gestational week 15 , serotonin cell bodies are in their typical organisation in the raphe nuclei, comprised of nine distinct cell groups spanning from the medulla oblongata through to the midbrain. The caudal division of cell bodies (B1-B5) project serotonergic fibres to the spinal cord, whilst the rostral division (B6-B9) provides the major ascending serotonergic fibres to areas throughout the forebrain, including the cerebral cortex, hippocampus and basal ganglia, and account for $85 \%$ of all serotonergic neurons (Glover and Clinton, 2016; Hornung, 2003; Törk, 1990) (Sodhi and Sanders-Bush, 2004). Serotonin signals through 7 receptor families, $5-\mathrm{HT}_{1}$ 7, most of which are G-protein coupled, except the ionotropic $5 \mathrm{HT}_{3}$ receptor subtype (Figure 1). The action of serotonin in the synaptic cleft is terminated by its reuptake by presynaptic SERT and subsequent metabolism by monoamine oxidase $A$ (MAO-A) to 5hydroxyindoleacetic acid (5-HIAA). 


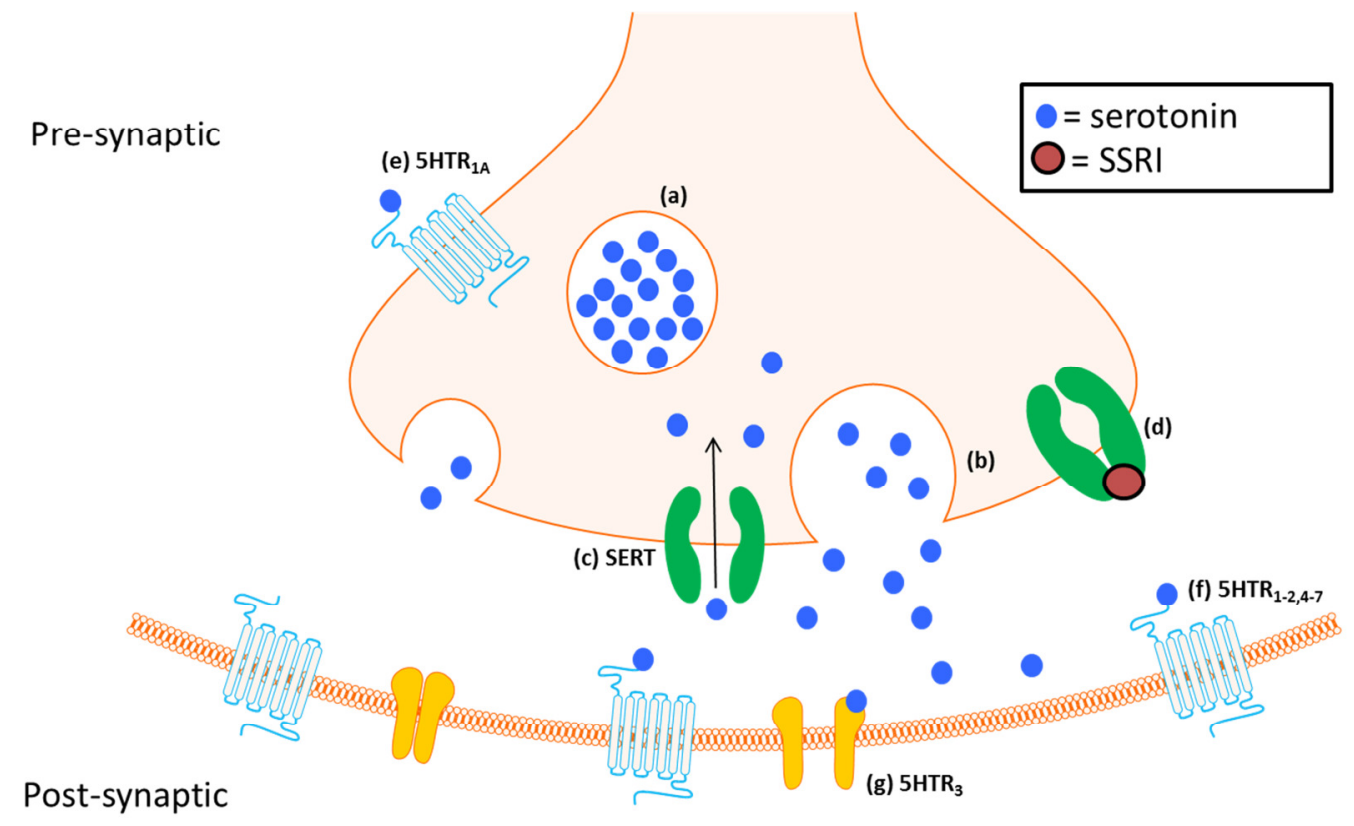

Figure 1. Selective serotonin reuptake inhibitors (SSRIs) block the serotonergic transporter (SERT), which inhibits the reuptake of serotonin, raising synaptic serotonin concentrations that causes prolonged and exaggerated serotonin receptor activation. Serotonin exerts its effects via a myriad of g-protein coupled receptors $\left(5 \mathrm{HTR}_{1-2,4-7}\right)$ and ionotropic receptor $\left(5 \mathrm{HTR}_{3}\right)$ subclasses. (a) Serotonin-containing vesicles fuse with the pre-synaptic membrane; (b) spilling their contents into the synaptic cleft. (c) SERT removes serotonin from the synaptic cleft, modulating the action of serotonin on its receptors. (d) SSRIs bind to SERT and inhibit removal of serotonin from the cleft. (e) Activation of presynaptic and (f) (g) postsynaptic serotonin receptors exerts varying inhibitory and excitatory effects depending on the subclass and location, and regulates synaptic transmission and associated signaling cascades.

In the human brain, SERT expression begins in parallel with the emergence of serotonergic neurons; SERT positive fibres originating from the raphe nucleus reach the telencephalon at gestational week 8 , the subplate at gestational week 10 and the cortical plate at gestational week 13 (Verney et al., 2002). A similar neurodevelopmental pattern has been demonstrated in rodents (Figure 2); SERT expression arises in the serotonergic neurons of the raphe nuclei at mid-gestation (embryonic day 13) (Hansson et al., 1998; Rubenstein, 1998) and serotonin fibers project into the telencephalon by embryonic day 17, passing through the septal areas and spreading throughout the cerebral cortex (Sodhi and SandersBush, 2004). 
a) Rodents

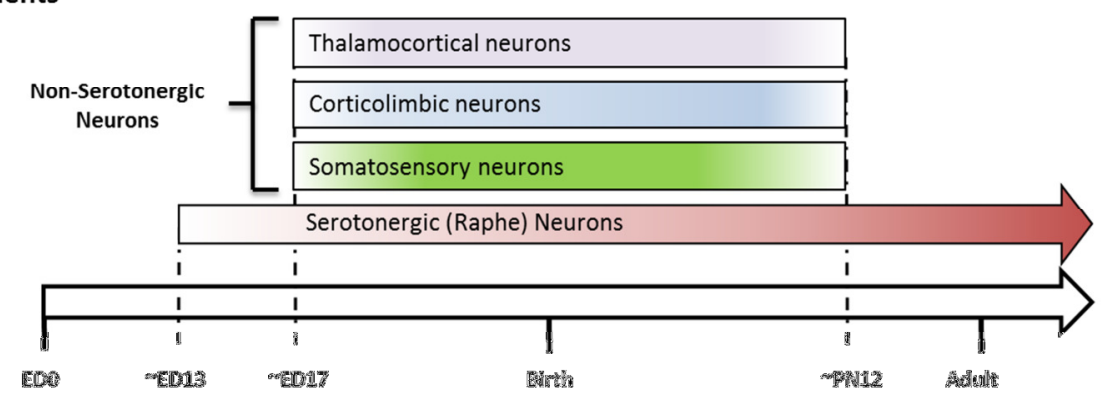

b) Humans

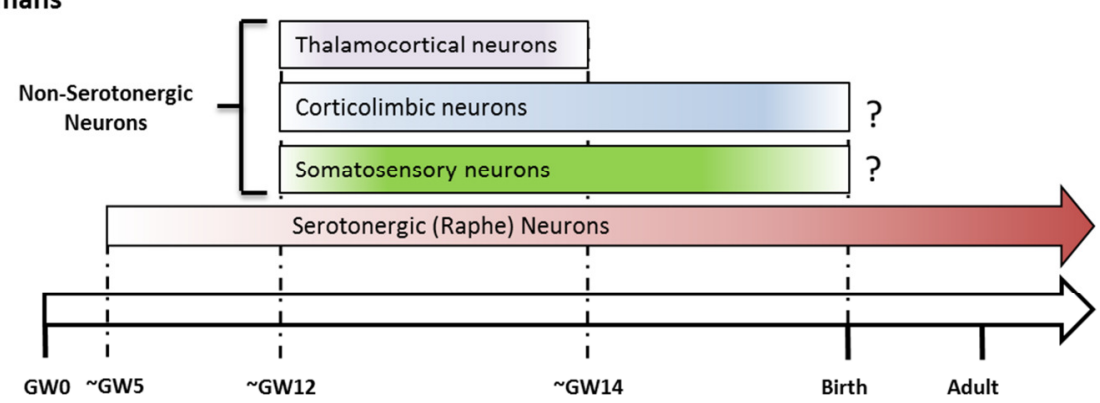

Figure 2. Schematic of SERT expression in rodents and humans from early gestation to adulthood. (a) In rodents, SERT expression follows a similar neurodevelopmental pattern as humans, beginning in the raphe neurons at Embryonic Day (ED) 13 then extending to nonserotonergic neurons at ED17; SERT expression on non-serotonergic neurons ceases in the rat brain by postnatal day (PN)12. (b) In humans, SERT expression arises in raphe neurons corresponding with the development of the serotonergic system at gestational week (GW) 5 , and remains through to adulthood. At $\sim$ GW12, SERT expression arises in non-serotonergic thalamocortical neurons. Whether transient SERT expression occurs in other nonserotonergic neurons in humans, similar to the rodent brain, remains to be determined. Figure adapted from Homberg et al., (2009).

While SERT is largely expressed on serotonergic neurons throughout neurodevelopment and maturity, it is also transiently expressed on non-serotonergic neurons. In the rodent brain, SERT expression has been shown to appear on non-serotonergic neurons, including glutamatergic neurons of thalamocortical pathways, pyramidal neurons in the prefrontal cortex and hippocampus (Chen et al., 2016, 2015), and also projection neurons of the somatosensory and corticolimbic systems, from approximately embryonic day 17 (Homberg et al., 2010; Narboux-Nême et al., 2008). Developmental SERT expression on non- 
serotonergic neurons in the rodent brain ceases in the first two weeks of postnatal life (equivalent to birth in humans (Semple et al., 2013), and is localised to serotonergic neurons in the mature brain (Narboux-Nême et al., 2008). Likewise in the human brain, an anatomically distinct set of non-serotonergic thalamocortical axons (i.e. internal capsule and corona radiata) have been observed to transiently express SERT between gestational weeks 12 and 14 (Verney et al., 2002). Whether this transient expression of SERT on nonserotonergic corticolimbic and somatosensory neurons also occurs in the human brain has not yet been determined.

The presence of SERT on non-serotonergic neurons and their ability to transiently capture serotonin during this early time period alludes to the possible involvement of serotonin in key neurodevelopmental processes of non-serotonergic systems. Studies have shown that serotonin plays a key role in the development of the neocortex by modulating the migration of cortical neurons (Riccio et al., 2011), and the formation of dendritic spines and branches, as well as dendritic length, in the hippocampus and cerebral cortex (Sodhi and SandersBush, 2004; Vitalis and Parnavelas, 2003). During telencephalic development, monoaminergic afferents and SERT-expressing thalamocortical axons are in close proximity along the internal capsule. These SERT-expressing thalamocortical axons have been shown to take up serotonin, and have been implicated in the migration and proliferation of developing glutamatergicneurons, potentially through subsequent serotonin release (Edgar and Price, 2001; Vitalis and Parnavelas, 2003; Whitworth et al., 2002). In addition, serotonin has been shown to modulate the response of developing thalamocortical axons to guidancecues, such as Netrin-1, via the serotonin receptor (5HTR $1 \mathrm{~B} / 1 \mathrm{D}$ ) (Bonnin et al., 2007). The serotonin $5 \mathrm{HT}_{\mathrm{A}}$ receptor is highly expressed in the telencephalic proliferative zone in early development, where it modulates cell division and proliferation (Hillion et al., 1994; Lidow and Rakic, 1995; Varrault et al., 1992; Vitalis and Parnavelas, 2003). Recently, studies have shown that serotonin influences the speed and trajectory of migrating GABAergic cortical interneurons via activation of $5 \mathrm{HT}_{3 \mathrm{~A}}$ receptors (Murthy et al., 2014), and also encourages the differentiation of early progenitor cells into glutamatergic neurons in the developing cerebral cortex (Lavdas et al., 1997). Taken together, these findings clearly implicate the serotonergic system as a key regulator of neurodevelopment, of which potential alterations caused by SSRI-exposure are summarized in Figure 3. 
Considering the critical role of the serotonergic system in neurodevelopment, it is feasible that manipulation of the serotonergic system during early development has the potential to cause broader disruptions in brain structure and circuitry and lead to associated disturbances in brain function and behaviour. Indeed, increased levels of serotonin during early development, modelled utilising SERT-knockout mice, was found to cause abnormal development of thalamocortical axons and underdevelopment of the somatosensory cortical barrels (Gaspar et al., 2003; Persico et al., 2001), as well as increases in anxiety- and depressive-like behaviours (Ansorge et al., 2004). Behavioural and biological alterations in other serotonergic system knockout models have also been reported with mutants showing increased ( $5 \mathrm{HT}_{1 \mathrm{~A}}$ receptor knockout) and decreased $\left(5 \mathrm{HT}_{2 \mathrm{C}}\right.$ and $5 \mathrm{~A}$ receptor knockout) anxiety levels, reductions in $\mathrm{GABA}_{A}$ receptor binding and hippocampal neurogenesis $\left(5 \mathrm{HT}_{1 \mathrm{~A}}\right.$ receptor knockout), as well as increased aggression in MAO-A (the enzyme responsible for $5 \mathrm{HT}$ degradation) knockout mice (for review see Gaspar et al., 2003). Therefore, altering the normal function of the serotonergic system can have broad implications on behavioural and biological phenotypes.

\subsection{The behavioural and biological effects of maternal SSRI treatment on exposed offspring: Evidence from human studies}

Taking into account the significant neurodevelopmental role that the serotonergic system plays and the widespread expression of SERT during gestation, manipulation to the serotonergic system could have major implications for human neurodevelopment and associated disorders. SSRIs administered during pregnancy are transferred across the placenta, resulting in prenatal SSRI exposure to the foetus; however, the extent and consequences of this exposure on the developing brain are unclear (Hendrick et al., 2001; Kim et al., 2006). Studies examining SSRI concentrations in foetal cord blood from treated mothers have reported concentrations of at least $50 \%$ compared to maternal levels (for review see Ewing et al., 2015). Additionally, two enzymes responsible for the metabolism of SSRIs in humans, cytochrome P450 2C and 2D6 (CYP2C and CYP2D6), are low or 
undetectable in the foetal liver but increase progressively during early life (Hines and McCarver, 2002; Sadler et al., 2016). Therefore, the foetus and neonate may be particularly sensitive to maternal SSRI exposure due to an inability to eliminate drugs through metabolism by the liver (Hiemke and Härtter, 2000; Kim et al., 2006).

Several studies observing birth outcomes of infants exposed to SSRIs in-utero (as early as the $1^{\text {st }}$ trimester and throughout pregnancy) have identified an increased risk for preterm delivery (Davis et al., 2007; Huang et al., 2014; Maschi et al., 2008; Reis and Källén, 2010), low Apgar scores (Casper et al., 2011, 2003; Jensen et al., 2013; Källén, 2004), increased risk for low birth weight (Huang et al., 2014; Oberlander et al., 2006; Reis and Källén, 2010), frequent intensive care unit admissions (Casper et al., 2011; Galbally et al., 2009), neonatal abstinence syndrome (i.e. effects of withdrawal caused by the cessation of SSRI exposure) (Levinson-Castiel et al., 2006; Nordeng et al., 2001) and risk for cardiac defects (Källén and Otterblad Olausson, 2007; Kornum et al., 2010; Pedersen et al., 2009). Whilst other studies report no significant association between prenatal SSRI exposure and cardiovascular anomalies (Davis et al., 2007) and pre-term birth (Hendrick et al., 2003), a recent study by Reefhuis et al., (2015), suggested that the potential teratogenicity of SSRIs was drugspecific. Using a Bayesian analysis approach, combining results from independent published studies together with data from a multicentre population-based case-control study of birth defects, the authors concluded that only fluoxetine and paroxetine were associated with increased risk of cardiac defects, while paroxetine alone was associated with an increased risk for anencephaly and atrial septal defects (Reefhuis et al., 2015).

While traditional assessments of drug safety during pregnancy have focused on structural or teratogenic defects to exposed offspring, more recent research has focused on the possible long-term effects on brain function, behaviour and the development of neurodevelopmental disorders. Several studies have examined the effects of maternal antidepressant drug treatment on offspring behaviour and risk of neurodevelopmental and psychiatric disorders, with a primary focus on ADHD and ASD (Table 1). These studies exhibit an apparent division into longitudinal studies that track the development of offspring from antidepressant-treated mothers and studies that track the familial history of offspring with ADHD and ASD. While the results of these studies are varied, there is evidence to suggest a possible association between maternal antidepressant drug use and ASD and/or ADHD and 
their associated behaviours in exposed offspring. Four out of eight retrospective studies reported significant increases in the risk of ASD following prenatal exposure to antidepressant (primarily SSRI) treatment (Boukhris et al., 2016; Croen et al., 2011; Gidaya et al., 2014; Harrington et al., 2014). Of these studies, two found that maternal SSRI treatment was associated with a 2 - fold increased risk in the development of ASD in offspring, with a three-fold increase in risk observed when exposure occurred in the first trimester (Croen et al., 2011; Harrington et al., 2014). Moreover, Croen et al., (2011) found no increase in the risk of ASD in offspring of mothers with a history of depression or any other health disorder in absence of prenatal SSRI treatment, suggesting that SSRI exposure plays an influential role (Croen et al., 2011). Conversely, another study reported that maternal history of depression was associated with a greater risk for ASD in offspring, with an even greater risk observed when combined with maternal SSRI treatment (Rai et al., 2013). While these studies are somewhat conflicting, SSRI treatment could be an indicator of maternal depressive symptom severity that could also contribute to the greater risk of ASD reported in these studies. Interestingly, one study reported that SSRI exposure prior to, but not during pregnancy, increased the risk for ASD in offspring (Clements et al., 2015), further suggesting that the observed risk for ASD as the result of prenatal SSRI exposure is possibly confounded by severity of maternal mental illness. Unfortunately, the measure in severity of maternal mental illness in these studies was based on measures such as frequency of past hospital admissions, which may be insufficient to truly capture symptom severity differences between participants. Nonetheless, Croen et al (2011) did report an increase in risk of ASD in offspring exposed to SSRIs in pregnancy, despite taking into consideration maternal mental health symptom severity and history (Croen et al., 2011) suggesting that symptom severity and history alone may not influence the risks.

Of the retrospective studies that investigated cases of ADHD, two reported a significantly increased risk associated with SSRI exposure and this behavioural disorder (Clements et al., 2015; Figueroa, 2010). One study reported that SSRI treatment during, but not prior to pregnancy was associated with an increased risk for ADHD in offspring (Clements et al., 2015), suggesting that exposure plays an influential role. In comparison to these findings, another study reported an increased risk of ADHD in children of women exposed to SSRIs postnatally only, proposing greater emphasis on the influence that maternal mood disorders 
play during pregnancy; however, the influence of SSRI-exposure through breast milk on offspring cannot be ruled out (Figueroa, 2010). Differences in sample sizes, ages and methodology may have contributed to the conflicting findings. For example Clements et al., (2015) recruited data from cases of $\operatorname{ADHD}(n=2,243)$ in offspring aged 2-19 years, then identified those exposed to maternal SSRIs ( $n=62$ ), whilst Figueroa et al., (2010) recruited data from pregnancies with SSRI exposure $(n=916)$ and aligned with cases of ADHD $(n=23)$ in offspring aged 0-5 years.

Collectively, with the exception of Malm et al., (2016), who reported an increased risk for depression in adolescent offspring exposed prenatally to SSRIs, the retrospective studies largely neglect the assessment of symptoms specific to anxiety and depressive disorders or later adolescent ages, and focus instead on ASD, ADHD and the juvenile ages, making it difficult to posit the potential longer term effects of maternal SSRI exposure. In addition, though the majority of the retrospective studies indicate that maternal SSRI exposure may increase the risk for developmental disorders in offspring, it is obvious that the exposure period that confers the greatest risk is much deliberated.

While retrospective studies provide the opportunity for large sample sizes and relative ease in data collection, they are limited by their inability to confirm SSRI use/compliance or symptom severity of maternal mood disorders during pregnancies. In comparison, despite lower samples sizes, longitudinal studies have the added benefit of examining more specific subject behaviours and measures of neurodevelopment and associated disorders. Of the ten published longitudinal studies, five reported no significant effects of SSRI exposure on behavioural parameters, as measured using the Bayley Scales of Infant and Toddler Development Instrument (BSID) administered by trained clinicians (Austin et al., 2013; Casper et al., 2003; Galbally et al., 2011) and the Child Behaviour Checklist (CBCL), a subjective, observational questionnaire completed by subject parents or caregivers (Misri et al., 2006; Nulman et al., 2012). The BSID assesses motor, language and cognitive development of infants and toddlers aged 0-3.5, whilst the CBCL aims to measure problem behaviour in children characterized by internalizing, such as withdrawal and anxiety, and/or externalising, such as delinquent or aggressive behaviours (Nøvik, 1999). These studies include small sample sizes $(n=13-35)$ that may have limited statistical power to detect any associations. Conversely, five studies with larger sample sizes $(n=28-5,531)$ have reported 
significant associations between maternal SSRI exposure and behavioural disturbances in offspring, including autistic traits, anxiety and externalizing behaviours. These studies were conducted in cohorts of slightly older children (up to 6 years of age) assessed using the $\mathrm{CBCL}$ (Hanley et al., 2015; Hermansen et al., 2016; Marroun et al., 2014; Oberlander et al., 2010) and BSID (Hanley et al., 2013). The question of whether the conflicting nature of these findings is due to the different methodology employed, or other factors such as sample size and age of subjects, needs further investigation. Furthermore, it must be acknowledged that several longitudinal studies lack effective comparison groups that enable separation of the effects of SSRI exposure from the effects of maternal depression (Austin et al., 2013; Galbally et al., 2011; Hanley et al., 2013; Misri et al., 2006; Oberlander et al., 2010). In addition, the longitudinal studies only examine the juvenile years and as such emotional disturbances, such as depression and anxiety, that commonly emerge during adolescent years, were not measured (Paus et al., 2008). Therefore, further studies examining later time periods would help provide a complete spectrum of potential neurobehavioural alterations associated with developmental SSRI exposure. 
Table 1: Effects of maternal SSRI exposure on offspring neurodevelopmental disorders: evidence from human studies.

\begin{tabular}{|c|c|c|c|c|}
\hline Study & Antidepressants & $\begin{array}{l}\text { Participants }(\mathrm{n}) \text { with or } \\
\text { without symptomology of } \\
\text { Major Depressive Disorder } \\
\text { (+/- MDD) }\end{array}$ & $\begin{array}{l}\text { Age of } \\
\text { offspring } \\
\text { studied }\end{array}$ & Findings \\
\hline \multicolumn{5}{|c|}{ Longitudinal Studies } \\
\hline $\begin{array}{l}\text { Austin et al., } \\
\text { (2013) }\end{array}$ & $\begin{array}{l}\text { SSRIs } \\
\text { (Fluoxetine, Sertraline, } \\
\text { Citalopram, Escitalopram, } \\
\text { Paroxetine, Fluvoxamine) } \\
\text { SNRI } \\
\text { (venlafaxine) } \\
\text { TCA } \\
\text { (Dothiepin) }\end{array}$ & $\begin{array}{l}n=35 \text { treated/exposed } \\
+M D D \\
n=23 \text { controls untreated } \\
-M D D\end{array}$ & $\begin{array}{l}17-24 \\
\text { months }\end{array}$ & $\begin{array}{l}\text { Nil significant effects of in-utero SSRI exposure on } \\
\text { motor, language or cognitive development - assessed } \\
\text { using the Bayley Scales of Infant and Toddler } \\
\text { Development instrument (BSID-III). }\end{array}$ \\
\hline Misri et al., & SSRIs & $\mathrm{n}=22$ treated/exposed & $4-5$ years & Nil significant differences between groups in \\
\hline
\end{tabular}




\begin{tabular}{|c|c|c|c|c|}
\hline (2006) & $\begin{array}{l}\text { (Fluoxetine, Sertraline, } \\
\text { Paroxetine) }\end{array}$ & $\begin{array}{l}+ \text { MDD } \\
n=14 \text { controls untreated } \\
-M D D\end{array}$ & & $\begin{array}{l}\text { internalizing behaviours, based on parental/teacher self- } \\
\text { report using the Child Behaviour Checklist (CBCL) (which } \\
\text { is designed to screen for psychological disorders and } \\
\text { associated behaviours, including anxiety, depression, } \\
\text { social interaction, aggressiveness, attention and } \\
\text { cognition)(Mazefsky et al., 2011) }\end{array}$ \\
\hline $\begin{array}{l}\text { Oberlander et } \\
\text { al., (2010) }\end{array}$ & $\begin{array}{l}\text { SSRIs (fluoxetine, paroxetine, } \\
\text { sertraline, venlafaxine, } \\
\text { Citalopram) }\end{array}$ & $\begin{array}{l}n=33 \text { treated/exposed } \\
+M D D \\
n=42 \text { controls untreated } \\
-M D D\end{array}$ & 3 years & $\begin{array}{l}\text { Children exposed to SSRIs and maternal depressed } \\
\text { mood had significantly increased internalizing } \\
\text { behaviours reported using the } C B C L \text {. }\end{array}$ \\
\hline $\begin{array}{l}\text { Galbally et } \\
\text { al., (2011) }\end{array}$ & $\begin{array}{l}\text { SSRIs } \\
\text { (sertraline, venlafaxine, } \\
\text { citalopram) }\end{array}$ & $\begin{array}{l}n=22 \text { treated/exposed } \\
+M D D \\
n=19 \text { controls untreated } \\
-M D D\end{array}$ & $\begin{array}{l}19-35 \\
\text { months }\end{array}$ & $\begin{array}{l}\text { Children exposed to SSRIs scored lower on motor } \\
\text { subscales, particularly fine motor and gross motor, using } \\
\text { the BSID-II. Nil significant effects on infant language and } \\
\text { cognitive development. }\end{array}$ \\
\hline $\begin{array}{l}\text { Hermansen et } \\
\text { al., (2016) }\end{array}$ & $\begin{array}{l}\text { SSRIs (Fluoxetine, Paroxetine, } \\
\text { Sertraline, Escitalopram and } \\
\text { citalopram) } \\
\text { SNRI (Venlafaxine) } \\
\text { Mirtazapine }\end{array}$ & $\begin{array}{l}n=28 \text { treated/exposed } \\
+M D D \\
n=42 \text { controls untreated } \\
+M D D \\
n=33 \text { controls untreated } \\
-M D D\end{array}$ & $5-6$ years & $\begin{array}{l}\text { Children exposed to SSRIs had significantly increased } \\
\text { internalizing and externalizing behaviour measured by } \\
\text { the CBCL. }\end{array}$ \\
\hline
\end{tabular}




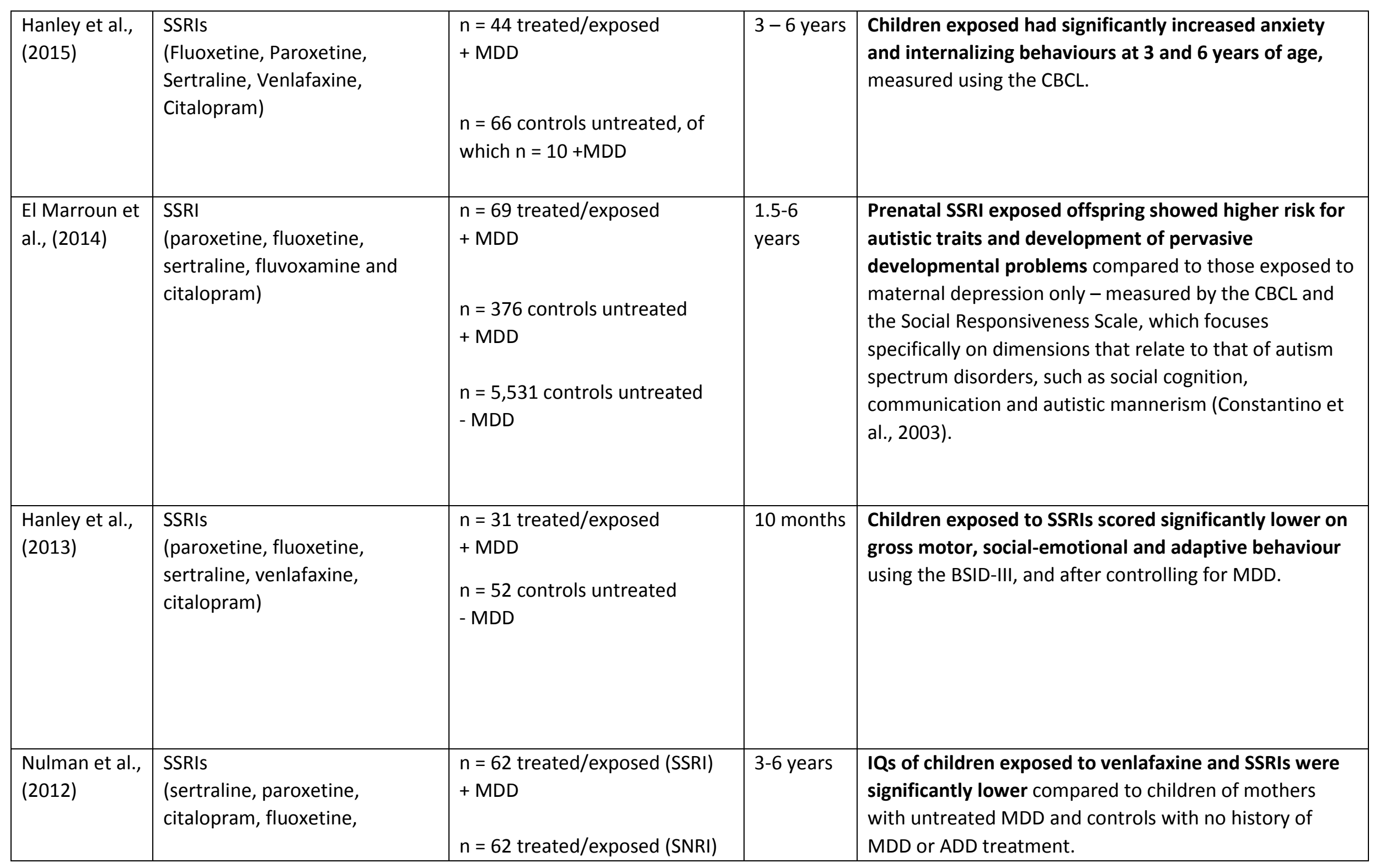




\begin{tabular}{|c|c|c|c|c|}
\hline & $\begin{array}{l}\text { fluvoxamine). } \\
\text { SNRIs } \\
\text { (venlafaxine) }\end{array}$ & $\begin{array}{l}+ \text { MDD } \\
n=54 \text { controls untreated } \\
+M D D \\
n=62 \text { controls untreated } \\
-M D D\end{array}$ & & $\begin{array}{l}\text { Nil significant differences in cognitive or behavioural } \\
\text { abnormalities of exposed groups assessed using the } \\
\text { Child Behaviour Checklist. }\end{array}$ \\
\hline $\begin{array}{l}\text { Hviid et al., } \\
\text { (2013) }\end{array}$ & $\begin{array}{l}\text { SSRIs (fluoxetine, sertraline, } \\
\text { paroxetine, citalopram, } \\
\text { escitalopram, fluvoxamine) }\end{array}$ & $\begin{array}{l}n=6,068 \text { SSRI exposed of } \\
\text { which } \\
n=835 \text { mothers }+ \text { MDD } \\
n=52 \text { offspring }+ \text { ASD } \\
n=620,807 \text { control of which } \\
2647 \text { mothers }+ \text { MDD }\end{array}$ & $\begin{array}{l}0-10 \\
\text { years }\end{array}$ & $\begin{array}{l}\text { SSRI use during pregnancy was not associated with an } \\
\text { altered risk of ASD. }\end{array}$ \\
\hline $\begin{array}{l}\text { Sorensen et } \\
\text { al., (2013) }\end{array}$ & SSRIs, SNRI, TCA & $\begin{array}{l}n=8,833 \text { ADD exposed, of } \\
\text { which } \\
n=1,756 \text { mothers }+ \text { MDD } \\
n=104+\text { ASD } \\
\text { Of those exposed to ADD; } \\
n=7,506 \text { SSRI exposed } \\
n=673 \text { SNRI exposed } \\
n=642 \text { TCA exposed }\end{array}$ & $5-9$ years & $\begin{array}{l}\text { Prenatal exposure to SSRIs was not associated with a } \\
\text { significantly altered risk for ASD in offspring. }\end{array}$ \\
\hline
\end{tabular}




\begin{tabular}{|c|c|c|c|c|}
\hline & & $\begin{array}{l}n=646,782 \text { controls, of which; } \\
n=4,324 \text { mothers }+ \text { MDD } \\
n=5,333+\text { ASD }\end{array}$ & & \\
\hline $\begin{array}{l}\text { Boukhris et } \\
\text { al., (2016) }\end{array}$ & $\begin{array}{l}\text { SSRIs, SNRIs, TCA, Monoamine } \\
\text { Oxidase Inhibitors (MAOI) }\end{array}$ & $\begin{array}{l}n=4724 \text { ADD exposed, of } \\
\text { which; } \\
n=46+\text { ASD } \\
n=3290 \text { mothers }+ \text { MDD } \\
n=140,732 \text { controls, of which; } \\
n=1008+\text { ASD } \\
n=14,651 \text { mothers + MDD }\end{array}$ & $\begin{array}{l}0-11 \\
\text { years }\end{array}$ & $\begin{array}{l}\text { SSRI use was associated with increased risk of ASD in } \\
\text { offspring, when exposed in the second and/or third } \\
\text { trimester only (HR 1.87), after accounting for } \\
\text { confounders. }\end{array}$ \\
\hline $\begin{array}{l}\text { Brown et al., } \\
\text { (2017) }\end{array}$ & SSRIs & $\begin{array}{l}n=2837 \text { pregnancies ADD } \\
\text { exposed, of which; } \\
n=1176+\text { Bipolar or MDD } \\
n=2364 \text { other } \\
\text { depressive/anxiety disorder } \\
n=58 \text { offspring +ASD } \\
n=33069 \text { pregnancies without } \\
\text { ADD exposure, of which; } \\
n=3175+\text { Bipolar or MDD } \\
n=13589 \text { other } \\
\text { depressive/anxiety disorder } \\
n=335 \text { offspring +ASD }\end{array}$ & $\begin{array}{l}4-12 \\
\text { years }\end{array}$ & $\begin{array}{l}\text { In-utero SSRI exposure was not associated with } \\
\text { increased risk of ASD in offspring. }\end{array}$ \\
\hline
\end{tabular}




\begin{tabular}{|c|c|c|c|c|}
\hline $\begin{array}{l}\text { Figueroa } \\
(2010)\end{array}$ & SSRIs, Bupropion, TCA & $\begin{array}{l}n=1030 \text { ADD exposed, of } \\
\text { which; } \\
n=28+A D H D \\
n=3532 \text { children of mothers } \\
+M D D, \text { of which; } \\
n=88+A D H D \\
n=29,329 \text { children of mothers } \\
-M D D, \text { of which; } \\
n=239+A D H D\end{array}$ & $0-5$ years & $\begin{array}{l}\text { Significant increase in ADHD in offspring exposed to } \\
\text { SSRIs postnatally, and not before/during pregnancy (OR } \\
\text { 2.04). } \\
\text { Significant increase in ADHD in offspring exposed to } \\
\text { Bupropion during pregnancy, and not before/after (OR } \\
\text { 3.63). }\end{array}$ \\
\hline $\begin{array}{l}\text { Brandlistuen } \\
\text { et al., (2015) }\end{array}$ & SSRIs, TCA, Other & $\begin{array}{l}n=141 \text { ADD exposed, of which; } \\
n=90+M D D \\
n=20,039 \text { not exposed, of } \\
\text { which; } \\
n=3831+M D D\end{array}$ & $0-3$ years & $\begin{array}{l}\text { Significant increase in anxiety symptoms in offspring } \\
\text { exposed to ADDs ( } r=0.64, p<0.05 \text { regression analysis) } \\
\text { after adjusting for MDD during pregnancy, MDD history, } \\
\text { smoking, alcohol and co-medication. Measured using the } \\
\text { CBCL. }\end{array}$ \\
\hline $\begin{array}{l}\text { Clements et } \\
\text { al., (2015) }\end{array}$ & $\begin{array}{l}\text { Antidepressants (categorized by } \\
\text { their 5-HT transporter affinity - } \\
\text { High: fluoxetine, paroxetine, } \\
\text { duloxetine, sertraline, } \\
\text { escitalopram. } \\
\text { Moderate: citalopram, } \\
\text { fluvoxamine, venlafaxine. }\end{array}$ & $\begin{array}{l}n=1,377 \text { ASD, of which } \\
n=128 \text { ASD subjects had a } \\
\text { mother with history of }+ \text { MDD } \\
n=4,022 \text { controls, of which } \\
n=225 \text { subjects had mother + } \\
\text { MDD } \\
n=2,243 \text { ADHD, of which } \\
n=184 \text { subjects had mother }+ \\
\text { MDD }\end{array}$ & 2-19 years & $\begin{array}{l}\text { ADD exposure during but not prior to pregnancy was } \\
\text { associated with ADHD (OR 1.69), after adjusting for } \\
\text { MDD } \\
\text { ADD use prior to pregnancy but not during was } \\
\text { associated with ASD (OR 1.91), after adjusting for MDD }\end{array}$ \\
\hline
\end{tabular}




\begin{tabular}{|c|c|c|c|c|}
\hline & $\begin{array}{l}\text { Low: nefazodone, bupropion, } \\
\text { mirtazapine). }\end{array}$ & $\begin{array}{l}n=5,631 \text { controls, of which } \\
n=214 \text { subjects had mother }+ \\
M D D\end{array}$ & & \\
\hline $\begin{array}{l}\text { Gidaya et al., } \\
\text { (2014) }\end{array}$ & $\begin{array}{l}\text { SSRIs (fluoxetine, citalopram, } \\
\text { paroxetine, sertraline, } \\
\text { fluvoxamine, escitalopram). }\end{array}$ & $\begin{array}{l}n=5,215 \text { ASD, of which; } \\
n=76 \text { SSRI exposed } \\
n=55 \text { mothers }+ \text { MDD } \\
n=52,150 \text { controls } \\
\text { Of which; } \\
n=365 \text { SSRI exposed } \\
n=347 \text { mothers }+ \text { MDD }\end{array}$ & $8-17$ years & $\begin{array}{l}\text { In utero exposure to SSRIs increased risk for ASD (OR } \\
\text { 1.8), after adjusting for maternal depression and any } \\
\text { SSRI indication. }\end{array}$ \\
\hline $\begin{array}{l}\text { Harrington et } \\
\text { al., (2014) }\end{array}$ & $\begin{array}{l}\text { SSRIs (fluoxetine, sertraline, } \\
\text { paroxetine, citalopram, } \\
\text { escitalopram) }\end{array}$ & $\begin{array}{l}n=492 \text { ASD, of which } 122 \\
\text { mothers }+ \text { MDD } \\
n=154 \text { developmental delay, } \\
\text { of which } 40 \text { mothers + MDD } \\
n=320 \text { controls, of which } 67\end{array}$ & $\begin{array}{l}2 \text { to } 5 \\
\text { years }\end{array}$ & $\begin{array}{l}\text { SSRI use associated with greater risk of ASD (OR 2.91), } \\
\text { with strongest association occurring with first-trimester } \\
\text { exposure (OR 3.22) and developmental delay in boys (OR } \\
\text { 3.39) (authors report invalid sample size for girls) }\end{array}$ \\
\hline
\end{tabular}




\begin{tabular}{|c|c|c|c|c|}
\hline & & mothers + MDD & & \\
\hline $\begin{array}{l}\text { Malm et al., } \\
\text { (2016) }\end{array}$ & $\begin{array}{l}\text { SSRIs (fluoxetine, sertraline, } \\
\text { paroxetine, citalopram, } \\
\text { escitalopram, fluvoxamine) }\end{array}$ & $\begin{array}{l}n=15,729 \text { SSRI exposed, of } \\
\text { which; } \\
n=60+\text { ASD } \\
n=160+\text { ADHD } \\
n=60+\text { Depression } \\
n=65+\text { Anxiety } \\
n=9,651 \text { maternal psychiatric } \\
\text { disorder, no SSRI, of which; } \\
n=79+\text { ASD } \\
n=137+\text { ADHD } \\
n=30+\text { Depression } \\
n=39+\text { Anxiety } \\
n=31,394 \text { controls, nil SSRI } \\
\text { exposure, nil maternal } \\
\text { psychiatric disorders, of which; } \\
n=100+\text { ASD } \\
n=124+\text { ADHD } \\
n=30+\text { Depression } \\
n=62+\text { Anxiety }\end{array}$ & $\begin{array}{l}0-14 \\
\text { years }\end{array}$ & $\begin{array}{l}\text { SSRI exposure was associated with increased rates of } \\
\text { depression in early adolescence (HR 1.78) but not with } \\
\text { ASD or ADHD. }\end{array}$ \\
\hline $\begin{array}{l}\text { Rai et al., } \\
\text { (2013) }\end{array}$ & SSRI, TCA & $\begin{array}{l}n=4,429 \text { ASD, of which } 44 \\
\text { mothers }+ \text { MDD } \\
n=43,277 \text { control, of which } \\
272 \text { mothers + MDD }\end{array}$ & $0-17$ years & $\begin{array}{l}\text { Maternal history of depression was associated with a } \\
\text { higher risk of ASD in offspring (OR 1.49). Of the } \\
\text { subsample with available data on ADD exposure, this } \\
\text { association was limited to women reporting ADD use } \\
\text { during pregnancy. }\end{array}$ \\
\hline
\end{tabular}


Abbreviations: $A D D=$ Antidepressant Drug; $A D H D=$ Attention Deficit Hyperactivity Disorder; ASD = Autism Spectrum Disorders; BSID = Bayley Scales of Infant and Toddler Development instrument; HR = Hazards Ratio; MDD = Major Depressive Disorder; OR = Odds Ratio; SNRI = Serotonin and Norepinephrine Reuptake Inhibitors; SSRI = Selective Serotonin Reuptake Inhibitors; TCA = Tricyclic Antidepressants. 
While there has been minimal investigation of the neuro-biological consequences of foetal SSRI exposure, the limited studies that have been conducted (Bellissima et al., 2015; Davidson et al., 2009; Laine et al., 2003; Oberlander et al., 2008; Pawluski et al., 2012, 2009) have focused primarily on aspects of the hypothalamic-pituitary-adrenal (HPA) axis and neurotransmitter metabolites in cord blood samples, with an absence of studies focusing on longer term changes. One study reported significantly decreased serotonin and its main metabolite, 5HIAA, by as much as $67 \%$ in the cord blood of SSRI exposed infants compared to controls (Laine et al., 2003), providing evidence that SSRIs may not necessarily increase foetal brain serotonin as it does in the adult brain. However, given that sources of foetal serotonin are dynamic and switch progressively during development from exogenous (placental) to endogenous (foetal raphe neurons) sources (Bonnin et al., 2011); caution needs to be taken when interpreting levels of serotonin in cord blood. Furthermore, another study reported a reduction in the dopamine metabolite, homovanillic acid (HVA), and a borderline reduction in cord blood noradrenaline (Laine et al., 2003), suggesting that SSRI exposure can influence neurotransmission systems beyond serotonin. The serotonergic system is a key regulator of the HPA axis and corticotropin releasing hormone (CRH) release is mediated by serotonergic transmission (Heisler et al., 2007b, 2007a). Accordingly, SSRI exposed infants have exhibited significantly decreased levels of cortisol in cord blood (Davidson et al., 2009) and in salivary samples at three months of age (Oberlander et al., 2008).

Recent studies have investigated other potential markers of neurobiological alterations caused by maternal SSRI exposure in human samples (Table 2). S100 calcium-binding protein $\beta(\mathrm{S} 100 \beta)$ is an astroglial-derived neurotrophic factor used as a marker of CNS cellular damage when detected at elevated biological concentrations (Kleindienst et al., 2007). One study reported significantly increased $S 100 \beta$ levels in maternal blood, amniotic fluid, cord blood and neonatal peripheral blood throughout pregnancy, at birth and 24hours postnatal following maternal treatment with the SSRI paroxetine compared to untreated controls (Bellissima et al., 2015). In addition, infants showing major neurological symptoms (i.e. hypotonia and seizures) at postnatal day 7 exhibited the highest blood S100 $\beta$ levels (Bellissima et al., 2015). Separating these findings in SSRI-treated mothers from the effects of innate maternal depression are difficult given that no control group for maternal 
depression was used (Bellissima et al., 2015), particularly when other studies suggest that untreated depressed subjects display higher levels of S100ß (Arolt et al., 2003; Grabe et al., 2001). On the other hand, another study reported decreased S100 $\beta$ levels in cord blood following SSRI exposure, even after controlling for maternal mood disorder, but reported significantly higher maternal S100 $\beta$ levels in SSRI treated subjects compared with nontreated (Pawluski et al., 2009). The conflicting findings regarding neonatal S100 $\beta$ levels between these two studies may be attributed to the specific SSRIs tested with Pawluski et al., (2009) collectively examining a range of SSRIs, whereas Bellissima et al., (2015) included data from those mothers treated with paroxetine only.

Finally, although levels of biological markers taken from blood provide some insight into the potential peripheral neurochemical perturbations occurring as the result of SSRI exposure, there is no guarantee that these peripheral measures accurately reflect changes in the brain. Further studies investigating the long-term effects of SSRI exposure on central neurotransmitter systems and their metabolites are required to elucidate the potential for these drugs to manipulate the developing brain. This last point is compounded given the purported role of the serotonergic system in the development of other systems, including glutamate and GABA (refer to section 1.2) and its relationship with neurotrophic markers such as BDNF, and their role in neurogenesis. 
Table 2: Effects of maternal antidepressant administration on biological measures in offspring: Evidence from human studies

\begin{tabular}{|c|c|c|c|c|}
\hline Study & Antidepressants & Participants (n) & Measurements Taken & Main Findings \\
\hline $\begin{array}{l}\text { Bellissima et al. } \\
\text { (2015) }\end{array}$ & $\begin{array}{l}\text { SSRI } \\
\text { (Paroxetine } \mathrm{n}=75 \text { ) }\end{array}$ & $\begin{array}{l}n=75 \text { SSRI exposed }+ \text { MDD or } \\
\text { other mood disorders } \\
n=231 \text { controls untreated } \\
- \text { MDD or other mood disorders }\end{array}$ & $\begin{array}{l}\text { S100ß protein } \\
\text { concentrations assessed } \\
\text { in maternal blood, } \\
\text { amniotic fluid, cord blood } \\
\text { and neonatal peripheral } \\
\text { blood. } \\
\text { Samples taken at: } \\
-16-20,27-30 \text { and } 35-40 \\
\text { weeks pregnancy } \\
\text { (maternal blood). } \\
\text { - Birth (amniotic fluid) } \\
\text { - } 24 \text { hours postnatal } \\
\text { (arterial and venous cord } \\
\text { blood). }\end{array}$ & $\begin{array}{l}\text { - Significant increase in } \mathrm{S} 100 \beta \text { levels in } \\
\text { maternal blood, amniotic fluid, and arterial and } \\
\text { venous cord blood at all time points. } \\
\text { \% Difference in median } \mathrm{S} 100 \beta \text { levels } \\
16-20 \text { weeks }(+233 \%) \\
27-30 \text { weeks }(+220 \%) \\
35-40 \text { weeks }(+157 \%) \\
\text { Birth }(+1425 \%) \\
24 \text { hours }(+829 \%)\end{array}$ \\
\hline
\end{tabular}




\begin{tabular}{|c|c|c|c|c|}
\hline & & & $\begin{array}{l}\text { - IGF-1 receptor (IGF-1R) } \\
\text { Urine (newborn) } \\
\text { - 5-HIAA }\end{array}$ & \\
\hline $\begin{array}{l}\text { Laine et al. } \\
\text { (2003) }\end{array}$ & $\begin{array}{l}\text { SSRIs } \\
\text { ( } \mathrm{n}=20 \text { Fluoxetine; } \\
\mathrm{n}=20 \text { Citalopram) }\end{array}$ & $\begin{array}{l}n=20 \text { SSRI exposed }(n=10+ \\
\text { MDD; } n=10+\text { panic disorder }) \\
n=20 \text { control untreated } \\
- \text { MDD or other mood disorders }\end{array}$ & $\begin{array}{l}\text { Birth (cord blood) } \\
\text { - 5-HT } \\
\text { - 5-HIAA } \\
\text { - Homovanillic Acid (HVA) } \\
\text { (dopamine metabolite) } \\
\text { - Noradrenaline } \\
\text { - Prolactin }\end{array}$ & $\begin{array}{l}\text { - Significantly decreased cord 5-HT (-67\%), 5- } \\
\text { HIAA }(-18 \%) \text { and HVA (-23\%), serum prolactin } \\
(-29 \%) \text { in the SSRI exposed infants compared } \\
\text { to control. } \\
\text { - Borderline significant decrease }(-46 \% ; p=0.05) \\
\text { cord Noradrenaline in SSRI exposed. }\end{array}$ \\
\hline $\begin{array}{l}\text { Oberlander et } \\
\text { al. (2008) }\end{array}$ & SSRIs & $\begin{array}{l}\mathrm{n}=31 \text { SSRI exposed (maternal } \\
\text { mood disorder history not } \\
\text { stated) } \\
n=45 \text { control untreated } \\
- \text { MDD or other mood disorders }\end{array}$ & $\begin{array}{l}\text { Cortisol collected at } 3 \\
\text { months' age (saliva) at } \\
\text { three daily time points, } \\
\text { before, during, and after } \\
\text { an information processing } \\
\text { task. } \\
\text { An additional measure of } \\
\text { cortisol was taken the } \\
\text { next day in the } \\
\text { afternoon/evening. }\end{array}$ & $\begin{array}{l}\text { - No significant differences in saliva cortisol } \\
\text { levels between infants during the time points } \\
\text { associated with the information processing task. } \\
\text { - Evening cortisol was significantly lower (-65\%) } \\
\text { in SSRI exposed infants compared to control. }\end{array}$ \\
\hline $\begin{array}{l}\text { Pawluski et al. } \\
\text { (2009) }\end{array}$ & $\begin{array}{l}\text { SSRIs } \\
\text { paroxetine } n=14 \text {, } \\
\text { fluoxetine } n=6 \text {, } \\
\text { sertraline } n=6 \text {, } \\
\text { citalopram } n=4\end{array}$ & $\begin{array}{l}n=36 \text { exposed }+ \text { MDD or other } \\
\text { mood disorders } \\
n=17 \text { controls untreated } \\
- \text { MDD or other mood disorders }\end{array}$ & $\begin{array}{l}\text { Birth (cord blood) } \\
\text { - S100 } \beta \mathrm{pg} / \mathrm{ml}\end{array}$ & $\begin{array}{l}\text { - Prenatal SSRI exposure significantly lowered (- } \\
16 \% \text { ) neonatal serum S100 } \beta \text { levels compared to } \\
\text { controls. }\end{array}$ \\
\hline
\end{tabular}




\begin{tabular}{|c|c|c|c|c|}
\hline $\begin{array}{l}\text { Pawluski et al., } \\
\text { (2012) }\end{array}$ & SSRIs & $\begin{array}{l}36 \text { Weeks ( } n \text { ) } \\
n=47 \text { control untreated }- \text { MDD } \\
\text { or other mood disorders } \\
n=29 \text { exposed }+ \text { MDD or other } \\
\text { mood disorders } \\
\text { Neonate }(n) \\
n=40 \text { control untreated }- \text { MDD } \\
\text { or other mood disorders } \\
n=25 \text { exposed }+ \text { MDD or other } \\
\text { mood disorders }\end{array}$ & $\begin{array}{l}\text { Serum at } 36 \text { weeks and } \\
\text { neonates (cord blood) } \\
\text { - Cortisol-binding globulin } \\
\text { (CBG) } \\
\text { - Cortisol } \\
\text { Saliva (infants 3month } \\
\text { old) } \\
\text { - cortisol }\end{array}$ & $\begin{array}{l}\text { - Significant increases in serum CBG }(+33 \%) \text { of } \\
\text { neonates exposed to SSRIs after vaginal } \\
\text { delivery. } \\
\text { - No significant differences in levels of other } \\
\text { measured parameters. }\end{array}$ \\
\hline
\end{tabular}

Abbreviations: SSRIs = selective serotonin reuptake inhibitors, IGF-I = insulin-like growth factor, IGF-IR = insulin-like growth factor receptor, TSH = thyroid stimulating hormone, 5-HT = 5-hydroxytryptamine, 5-HIAA = 5-hydroxyindoleacetic acid, HVA = homovanillic acid, DHPG = dihydroxyphenylglycine, S100B = S100 calcium-binding protein $B$. 


\subsection{Considerations for Human Studies}

Human studies are invaluable to clarify the risks associated with maternal SSRI exposure; yet they are confounded by the underlying maternal psychopathology and maternal stress or adversities. Furthermore, human studies often omit or report difficulties measuring the severity of maternal mood disorders, which may be phenotypically masked due to SSRI treatment, and could represent a considerable influence over the observed effects of SSRI exposure on offspring. As iterated by Petersen et al., (2014), SSRI use may be a marker of severity of underlying mental illness and that may confound the interpretation of these clinical findings. Therefore, careful consideration must be given to the interpretation of clinical studies and their implications for the broader population, especially when inherent difficulties in separating the effects of maternal SSRI exposure from confounding factors, such as maternal depression, are often overlooked.

Maternal mood disorders and adversity themselves are factors associated with a greater risk for obstetric complications, impaired pre- and post-natal care and the development of psychopathologies in children (Ashman et al., 2002; Davalos et al., 2012; Glover, 2014; Hammen and Brennan, 2003; Nulman et al., 2002; O'Connor et al., 2002). Systematic reviews have shown that untreated maternal depression is associated with increased markers of infant morbidity, including preterm birth, low birth weight, childhood emotional and behavioural problems and poor cognitive development (Davalos et al., 2012; Gentile, 2015; Steer et al., 1992). Studies have also noted neurobehavioural consequences of untreated maternal depression or maternal adversity on children, with some showing an increased risk for internalizing behaviours (Ashman et al., 2002), decreased cognitive and language development (Nulman et al., 2002), developmental delay (Deave et al., 2008) and an increased risk for depression, anxiety, ADHD and ASD symptomology (Glover, 2014; Hammen and Brennan, 2003; O'Connor et al., 2003, 2002; Rice et al., 2010; Rodriguez and Bohlin, 2005; Ronald et al., 2011; Van den Bergh and Marcoen, 2004). Untreated maternal depression can also have indirect effects on the offspring through means of unhealthy maternal behaviours, for example studies have found a significant association with pregnant women suffering from depression and cigarette, alcohol and cocaine use in some people (Zuckerman et al., 1989); all well-known to detrimentally affect pregnancy outcomes (Cnattingius, 2004; Eyler et al., 1998; Ornoy and Ergaz, 2010). Finally, prenatal depression 
remains one of the strongest risk factors for postnatal depression (Robertson et al., 2004); a disorder linked to developmental problems and increased risk of depression in children (Murray et al., 2011; Talge et al., 2007). Severe untreated depression, can also result in suicide, which is a major cause of maternal death (Oates, 2003). Therefore, SSRIs continue to be critically important to the health and well-being of mothers with depression and accordingly, current clinical guidelines from the American Psychiatric Association advise against the discontinuation of SSRI use in pregnancy (though switching from paroxetine may be advised in some instances), particularly if the chance of psychopathological relapse is high (Yonkers et al., 2009). Despite reports of increased risk associated with third trimester SSRI exposure and teratogenic effects or neonatal abstinence syndrome, tapering of SSRI dosage has also been recommended over discontinuation (Yonkers et al., 2009). Finally, although some clinical studies report $\sim 2-3 x$ fold increases in risks for neurodevelopmental disorders in offspring exposed to SSRIs (Boukhris et al., 2016; Clements et al., 2015; Croen et al., 2011; Gidaya et al., 2014; Harrington et al., 2014), the fact remains that the overall incidence/prevalence of these disorders in the population is relatively low (incident rate of 38.6 per 100,000 and prevalence of 6 per 1000 for ASD (Jensen et al., 2014; Newschaffer et al., 2007); and incidence rate of 9.9 per 100,000 and prevalence of 1 per 1000 for ADHD (Holden et al., 2013)). The low incidence of behavioural disorders in the general population warrants careful consideration in light of the consequences associated with untreated maternal depression and the risks this pathology poses for the health and wellbeing of the mother and child. Ultimately, this is clearly an area that requires further research with an emphasis on discerning the effects of maternal SSRI treatment from maternal psychopathology on the neurodevelopment and risk for associated disorders in offspring. 


\subsection{The behavioural and biological effects of maternal SSRI treatment on exposed offspring: Evidence from animal studies}

Given the inherent difficulties in assessing the effects of developmental SSRI exposure in humans, researchers have turned to animal models to gain a deeper understanding of the effects of maternal SSRI treatment on exposed offspring. To begin translation of the findings from animal models to the clinic, emphasis needs to be placed on the timeline of SSRIexposure, and the equivalent neurodevelopmental milestones reached compared to humans. In humans, the blood brain barrier is established at 23-32 weeks gestation, whilst gliogenesis, synaptogenesis and myelination contribute to the peak brain growth occurring at 36-40 weeks gestation (reviewed in Semple et al., (2013)). In rodents, these same milestones are reached at PN1 - 3 and PN7 - 10, respectively (Semple et al., 2013). Indeed, it has been estimated based on neurodevelopmental comparisons that rodent PN7 is equivalent to birth in humans (Clancy et al., 2007). Typically, rodent studies are divided into those that deliver SSRIs to dams during gestation (+/- lactation) and others that deliver SSRIS directly to pups in the early postnatal period. Despite wide variance in other methodological considerations, including drug dosage, administration method and treatment duration, it is clear that SSRI exposure in rodent models can alter neurodevelopment in ways that impact behavioural characteristics of offspring, including increases in anxiety- and depressive-like behaviours, as well as abnormalities in social interaction and exploratory behaviours (Table 3). With the exception of a few studies (Boulle et al., 2016a, 2016b; Glover et al., 2015; Kiryanova et al., 2016; Rayen et al., 2011), the current body of animal literature, does not assess the effects of SSRIs in a depression or anxiety model, overshadowing the clinical relevance of results. Considering depression and anxiety are associated with altered serotonergic development in their own right (Nulman et al., 2012), modelling SSRI exposure in a model of depression or anxiety that mimics the underlying serotonergic pathology may influence the effects of SSRIs on the serotonergic system.

Of the 13 studies assessing maternally administered SSRIs, 12 report significant increases in anxiety- or depressive-like behaviour and/or deficits in cognition in offspring ranging in age from PN8 to PN140 (Table 3). Specifically, seven of these studies demonstrated an increase in anxiety-like behaviours following doses ranging from $0.3-25 \mathrm{mg} / \mathrm{kg}$ Fluoxetine (Bairy et al., 2006; Boulle et al., 2016b; Lisboa et al., 2007; Noorlander et al., 2008; Olivier et al., 
2011; Smit-Rigter et al., 2012) and 10mg/kg citalopram (Sprowles et al., 2016), with exposure durations from GD0 to PN21. Six studies reported increases in depressive-like behaviour measured by the forced swim test, shock escape test and novelty-supressed feeding test (Boulle et al., 2016a; Glover et al., 2015; Lisboa et al., 2007; Noorlander et al., 2008; Rayen et al., 2011; Sprowles et al., 2016). Conversely, six studies found either no differences (Glover et al., 2015; Rayen et al., 2011), or decreases in anxiety-like behaviour (Francis-Oliveira et al., 2013; Kiryanova et al., 2016; McAllister et al., 2012), and no changes (Francis-Oliveira et al., 2013; Olivier et al., 2011) or decreases in depressive-like behaviour (Francis-Oliveira et al., 2013; McAllister et al., 2012). In addition, five studies assessed cognition, with one noting significant deficits in the passive avoidance test (Bairy et al., 2006), and another reporting reduced performance in the Morris water maze in SSRIexposed offspring; the latter study also reported increased prepulse inhibition (Sprowles et al., 2016). On the contrary, other studies reported no changes (Kiryanova et al., 2016; McAllister et al., 2012; Olivier et al., 2011), or increases in cognition (spatial memory) in the Morris water maze (Bairy et al., 2006). The differences in findings may be attributable to differences in drug dosages, subject sex and behavioural test protocols (Table 3). For example, one study reported a decrease in ambulation during the OFT in males only, but not females, and an increase in immobility time in the forced swim test specifically in females, following maternal fluoxetine exposure (Lisboa et al., 2007). Another study reported negligible alterations in the behaviour of female rodents exposed to a high dose of fluoxetine (McAllister et al., 2012), excluding males from the study. Further studies are required to assess the dose effects of SSRI exposure on offspring behaviour of both sexes.

Studies examining the effects of postnatal SSRI exposure (ranging from PNO - PN21) on offspring behaviour provided the greatest consistency in findings (Table 3). All studies reported significant increases in anxiety-like behaviour evident through decreases in exploration and/or increases in anxiogenic parameters in the open field test, elevated plus maze, light-dark test, novelty-induced hypophagia and novelty-suppressed feeding tests (Ansorge et al., 2008, 2004; Karpova et al., 2009; Lee, 2009; Lee and Lee, 2012; RodriguezPorcel et al., 2011; Zheng et al., 2011). Three studies assessed the effects of postnatal exposure on offspring depressive-like behaviour. Of those, two reported increases in learned helplessness in the shock escape test (Ansorge et al., 2008, 2004) and one reported 
decreased immobility time in the forced swim test (Karpova et al., 2009). The conflicting findings of the three latter studies are likely to be attributable to the different behavioural tests used to measure depressive-like behaviour, given that the drug dose and administration methods were similar. Indeed, although the forced swim test has been validated as an effective measure of antidepressant efficacy and depressive-like behaviour in rodents (Slattery and Cryan, 2012), others have suggested that in some cases immobility behaviour may resemble a survival mechanism rather than behavioural despair (Nishimura et al., 1988). Despite the relative consistency in findings of these studies exposing offspring to SSRIs postnatally, translation of the results must be taken with caution. In the clinical scenario, SSRIs are transferred via the mother in utero or through breast milk, which has been shown to influence the pharmacokinetics of SSRIs (Heikkinen et al., 2002; Velasquez and Bonnin, 2016). Therefore, directly exposing offspring to SSRIs postnatally could have an exaggerated influence on their behaviour and neurobiology. Nonetheless, these consistent findings suggest that the first 14 days of postnatal development in rodents, (third trimester in humans (Clancy et al., 2007)), a period marked by peak brain growth (Semple et al., 2013), represents a time period perhaps more vulnerable to the effects of developmental SSRI exposure.

As previously mentioned, the majority of animal studies assess the effects of developmental SSRI exposure in naïve rodents. A limited number assess the effects in models of maternal depression (Boulle et al., 2016a, 2016b; Glover et al., 2015; Kiryanova et al., 2016; Rayen et al., 2011), which arguably represents the clinical scenario more closely. Several studies have modelled SSRI exposure in dams exposed to environmental stress (as a model of maternal depression) through restraint, intense light exposure, confinement or other stressors (Table 3) (Boulle et al., 2016b, 2016a; Kiryanova et al., 2016; Rayen et al., 2011). Of those studies, two reported increased depressive-like behaviour in the forced swim test in SSRI-exposed offspring of maternally stressed dams (Boulle et al., 2016a; Rayen et al., 2011). Boulle et al., (2016a) reported an increase in immobility in the forced swim test in fluoxetine exposed female (but not male) Boulle et al., (2016b)) offspring regardless of maternal stress, whilst Rayen et al., (2011) reported increased immobility time in fluoxetine-exposed offspring of maternally stressed dams only. Another reported that SSRI-exposed offspring born of dams subjected to stress have decreased anxiety-like behaviour compared to SSRI-exposed 
offspring born of dams naïve to stress (Boulle et al., 2016b). Similarly, Kiryanova et al., (2016) reported a reduction in anxiety-like behaviour in male offspring of maternally stressed dams exposed to fluoxetine, suggesting that exposure could be beneficial in ameliorating the effects of maternal mood on offspring, at least in relation to anxietyrelated behaviour. In comparison to these studies, another study investigated the effects of maternal SSRI exposure in selectively bred rats to determine whether innate disturbances in emotional behaviour altered susceptibility (or resistance) to the effects of paroxetine treatment in offspring (Glover et al., 2015). Using selectively bred Sprague-Dawley rats that exhibited decreased anxiety-like behaviour (high responders) or increased anxiety-like behaviour (low responders), Glover et al., (2015) showed significantly greater immobility times (depressive-like behaviour) in the forced swim test in offspring of paroxetine-treated low responder dams, but no other differences in any parameters of the open field test, forced swim test and elevated plus maze (Glover et al., 2015). Taken together these findings suggest that the effects of developmental SSRI exposure can differ substantially in models of maternal adversity and depression (which appears to reflect the findings observed in the clinic). Furthermore, animal studies have highlighted an influence of sex on the effects of SSRI exposure in offspring that warrants further investigation. 
Table 3: Effects of maternal antidepressant administration on biological measures in exposed offspring: evidence from animal studies.

\begin{tabular}{|c|c|c|c|}
\hline $\begin{array}{l}\text { Study } \\
\text { (Shaded studies } \\
\text { indicates those } \\
\text { implementing } \\
\text { models of maternal } \\
\text { depression/adversit } \\
\text { y). }\end{array}$ & $\begin{array}{l}\text { Species, Strain, Drug Dose, Route and } \\
\text { Duration }\end{array}$ & Test and age performed & $\begin{array}{l}\text { Main Findings: } \\
\text { (SSRI-exposed offspring compared to control unless } \\
\text { otherwise stated. Percentages given are approximations) }\end{array}$ \\
\hline \multicolumn{4}{|c|}{ Prenatal/maternal exposure } \\
\hline Bairy et al., (2006) & $\begin{array}{l}\text { Species/Strain } \\
\text { Wistar Rats ( } n=16 \text { offspring/group) } \\
\text { Dose } \\
\text { Fluoxetine } 8 \text { and } 12 \mathrm{mg} / \mathrm{kg} \\
\text { Route and Duration } \\
\text { GD6 - GD20 Oral (dissolved in water) }\end{array}$ & $\begin{array}{l}\text { PN8-49 (pre-adolescence } \\
\text { to adolescence) } \\
\text { Negative Geotaxis (NG) } \\
\text { Open Field Test (OFT) } \\
\text { Rotarod Test (RT) } \\
\text { Morris Water Maze } \\
\text { (MWM) } \\
\text { Elevated Plus Maze (EPM) } \\
\text { Passive Avoidance (PA) }\end{array}$ & $\begin{array}{l}\text { NG }- \text { Flx } 8 \mathrm{mg} / \mathrm{kg} \text { increased time to turn } 180^{\circ} \text { at PN10 } \\
(+20 \%) \text { and PN12 (+53\%). } \\
\text { Flx } 12 \mathrm{mg} / \mathrm{kg} \text { decreased time to turn } 180^{\circ} \text { at PN10 (-6\%) an } \\
\text { increased time at PN12 (+44\%) } \\
\text { OFT - Increased central, peripheral and total crossings at } \\
\text { PN18 (Flx 8mg/kg: }+320 \%,+127 \% \text { and }+133 \% \text {. Flx } \\
12 \mathrm{mg} / \mathrm{kg}:+136 \%,+110 \% \text { and }+110 \%) \text {. Decreased central, } \\
\text { peripheral and total crossings at PN35 (Flx } 8 \mathrm{mg} / \mathrm{kg}:-52 \%,- \\
15 \% \text { and }-20 \% \text {. Flx } 12 \mathrm{mg} / \mathrm{kg}:-38 \%,-23 \% \text { and }-25 \%) \text {. No } \\
\text { differences on PN56. } \\
\text { RT - Increased retention time at PN22 (Flx } 12 \mathrm{mg} / \mathrm{kg} \text { : } \\
+350 \%) \text { and PN49 (Flx } 8 \text { and } 12 \mathrm{mg} / \mathrm{kg}:+70 \%) \\
\text { MWM - Flx } 8 \mathrm{mg} / \mathrm{kg}: \text { Decrease in time to escape at PN24 (- } \\
29 \%) \text {. Flx } 12 \mathrm{mg} / \mathrm{kg} \text { decrease time to escape at PN24 and } \\
\text { PN29 (-32\% and -50\%). }\end{array}$ \\
\hline
\end{tabular}




\begin{tabular}{|c|c|c|c|}
\hline & & & $\begin{array}{l}\text { PA - Flx } 12 \mathrm{mg} / \mathrm{kg} \text { : increase in latency to enter dark } \\
\text { compartment (+96\%) } \\
\text { EPM - No significant differences } \\
\text { Summary - SSRI exposure caused a transient delay in } \\
\text { motor development, favourable effect on cognition and } \\
\text { learning at higher doses and decreased exploratory } \\
\text { behaviour at adolescence. }\end{array}$ \\
\hline Glover et al., (2015) & $\begin{array}{l}\text { Species/Strain } \\
\text { Sprague-Dawley Rats (high responders } \\
\text { and low responders, } \mathrm{n}=24 \\
\text { offspring/group) } \\
\text { Dose } \\
\text { Paroxetine } 10 \mathrm{mg} / \mathrm{kg} \\
\text { Route and Duration } \\
7 \text { days prior to mating - PN21 Oral } \\
\text { (dissolved in water) }\end{array}$ & $\begin{array}{l}\text { PN75 (Adult) } \\
\text { Locomotor response to } \\
\text { novelty (LRN) } \\
\text { EPM } \\
\text { Forced Swim Test (FST) }\end{array}$ & $\begin{array}{l}\text { FST - exposed low-responders had increased immobility } \\
\text { compare to vehicle low-responders (+50\%). } \\
\text { LRN and EPM - no differences } \\
\text { Summary - SSRI exposure exacerbated low-responder's } \\
\text { depressive-like behaviour but had no effect on high } \\
\text { responders. }\end{array}$ \\
\hline Lisboa et al., (2007) & $\begin{array}{l}\text { Species/Strain } \\
\text { Swiss Mice ( } n=9-17 \text { offspring/group) } \\
\text { Dose } \\
\text { Fluoxetine } 7.5 \mathrm{mg} / \mathrm{kg} \\
\text { Route and Duration } \\
\text { GD0 - PN21 Gavage }\end{array}$ & $\begin{array}{l}\text { PN30-40 (Adolescence) } \\
\text { and PN70 (Adult) } \\
\text { OFT } \\
\text { EPM } \\
\text { FST } \\
\text { Intruder-resistant test (IRT) } \\
\text { Hot plate test (HPT) }\end{array}$ & $\begin{array}{l}\text { Male: } \\
\text { OFT - Decreased ambulation at PN40 (-16\%) } \\
\text { IRT - Increased latency to first attack (+65\%) } \\
\text { EPM, FST and HPT - no differences } \\
\text { Summary - Males: SSRI exposure induced decreased } \\
\text { exploratory behaviour at adolescence and decreased } \\
\text { reactivity/impulsivity in adults. } \\
\text { Female: } \\
\text { FST - Increased immobility both PN30 (+41\%) and PN70 } \\
\text { (+22\%) }\end{array}$ \\
\hline
\end{tabular}




\begin{tabular}{|c|c|c|c|}
\hline & & & $\begin{array}{l}\text { OFT, EPM and HPT - no differences } \\
\text { Summary - Females: SSRI exposure increased depressive- } \\
\text { like behaviour at both adolescence and adulthood. }\end{array}$ \\
\hline $\begin{array}{l}\text { Kiryanova et al., } \\
(2016)\end{array}$ & $\begin{array}{l}\text { Species/Strain } \\
\text { C57BL/6 Mice (n= 16-17 } \\
\text { offspring/group) } \\
\text { Dose } \\
\text { Fluoxetine } 25 \mathrm{mg} / \mathrm{kg} \\
\text { Route and Duration } \\
\text { GD15 to PN12 Oral (dissolved in } \\
\text { drinking water) } \\
\text { Stress (maternal depression model) } \\
\text { Combination of restricted access to } \\
\text { food, continuous lighting, cage tilt, } \\
\text { foreign object in cage, paired housing } \\
\text { of dams, soiled cage, irregular tones, } \\
\text { restraint and white noise from GD4 - } \\
\text { GD18. }\end{array}$ & $\begin{array}{l}\text { PN56 (Adult) } \\
\text { OFT } \\
\text { EPM } \\
\text { Passive Avoidance Test } \\
\text { (PAT) } \\
\text { MWM } \\
\text { Prepulse Inhibition (PPI) } \\
\text { IRT } \\
\text { Social Behaviour (SB) }\end{array}$ & $\begin{array}{l}\text { EPM - Increase time in open arms in both stressed and } \\
\text { non-stressed offspring (+96\%). } \\
\text { IRT - Increase in time spent (+223\%) engaged in } \\
\text { aggressive behaviour. } \\
\text { OFT, PAT, MWM and PPI - no difference } \\
\text { Summary - SSRI exposure caused decreases in anxiety and } \\
\text { increases in aggression in adulthood, largely independent } \\
\text { of maternal stress. }\end{array}$ \\
\hline Olivier et al., (2011) & $\begin{array}{l}\text { Species/Strain } \\
\text { Wistar Rats ( } n=7-16 \text { offspring/group) } \\
\text { Dose } \\
\text { Fluoxetine } 12 \mathrm{mg} / \mathrm{kg} \\
\text { Route and Duration } \\
\text { GD11 - PN1 Gavage }\end{array}$ & $\begin{array}{l}\text { PN28-35 (Adolescence) } \\
\text { and PN65 (Adult) } \\
\text { Novelty Suppressed } \\
\text { Feeding (NSF) } \\
\text { OFT } \\
\text { EPM } \\
\text { Conditioned Place Aversion } \\
\text { (CPA) }\end{array}$ & $\begin{array}{l}\text { NSF - increased latency to start eating (+110\%) } \\
\text { CPA - increased freezing time in the shock compartment } \\
(+5 \%) \\
\text { EPMS - decreased time spent in open arms (-45\%) } \\
\text { AdSP - decreased amount of pinning behaviour (-46\%) } \\
\text { OFT, EPM, FST, SPT, ASP and SeB - no difference } \\
\text { Summary - SSRI exposure caused increases in anxiety-like }\end{array}$ \\
\hline
\end{tabular}




\begin{tabular}{|c|c|c|c|}
\hline & & $\begin{array}{l}\text { EPM - After Stress (EPMS) } \\
\text { FST } \\
\text { Sucrose Preference Test } \\
\text { (SPT) } \\
\text { Adolescent Social Play } \\
\text { (ASP) } \\
\text { Adult Social Play (AdSP) }\end{array}$ & $\begin{array}{l}\text { behaviour. No effect on depressive-like behaviour was } \\
\text { observed. }\end{array}$ \\
\hline $\begin{array}{l}\text { Noorlander et al., } \\
\text { (2008) }\end{array}$ & $\begin{array}{l}\text { Species/Strain } \\
\text { C57BL/6 Mice ( } \mathrm{n}=5-13 \\
\text { offspring/group) } \\
\text { Dose } \\
\text { Fluoxetine } 0.3,0.6 \text { or } 0.8 \mathrm{mg} / \mathrm{kg} \\
\text { Fluvoxamine } 4.2 \mathrm{mg} / \mathrm{kg} \\
\text { Route and Duration } \\
\text { GD8 - } 18 \text { Intraperitoneal (IP) }\end{array}$ & $\begin{array}{l}\text { P20 (pre-adolescence) and } \\
\text { PN90 (adult) } \\
\text { EPM } \\
\text { OFT } \\
\text { NSF }\end{array}$ & $\begin{array}{l}\text { EPM - increased duration in closed arms at both PN20 } \\
\text { (Flx: }+23 \% \text {, Flv: } 14 \%) \\
\text { OFT - decreased distance travelled in the centre arena at } \\
\text { adulthood (Flx: }-56 \%) \\
\text { NSF - increased latency to feed at adulthood (FIx: }+240 \% \text { ) } \\
\text { Summary - SSRI exposure caused increases in anxiety-like } \\
\text { and depressive-like behaviour }\end{array}$ \\
\hline $\begin{array}{l}\text { McAllister et al., } \\
(2012)\end{array}$ & $\begin{array}{l}\text { Species/Strain } \\
\text { C57BL/6 Mice ( } \mathrm{n}=16-17 \\
\text { offspring/group) } \\
\text { Dose } \\
\text { Fluoxetine } 25 \mathrm{mg} / \mathrm{kg} \\
\text { Route and Duration } \\
\text { GD15 - PN12 Oral (dissolved in } \\
\text { drinking water) }\end{array}$ & $\begin{array}{l}\text { PN73 - } 83 \text { (adult) } \\
\text { EPM } \\
\text { OFT } \\
\text { Horizontal Ladder (HL) } \\
\text { FST } \\
\text { MWM } \\
\text { PPI } \\
\text { Fear Conditioning (FC) }\end{array}$ & $\begin{array}{l}\text { EPM - reduced time spent in closed arms (-21\%) } \\
\text { FST - longer latency to first bout of immobility (+25\%) } \\
\text { OFT, HL, MWM, PPI and FC - no difference } \\
\text { Summary - SSRI exposure caused decreases in anxiety- } \\
\text { and depressive-like behaviours. }\end{array}$ \\
\hline
\end{tabular}




\begin{tabular}{|c|c|c|c|}
\hline Boulle et al., (2016a) & $\begin{array}{l}\text { Species/Strain } \\
\text { Sprague-Dawley Rats ( } \mathrm{n}=13-16 \\
\text { offspring/group) } \\
\text { Dose } \\
\text { Fluoxetine } 5 \mathrm{mg} / \mathrm{kg} \\
\text { Route and Duration } \\
\text { PN1 - PN21 Osmotic Minipumps } \\
\text { Stress (maternal depression model) } \\
\text { Restraint 3x daily under bright light for } \\
45 \text { minutes from GD15 - GD21. }\end{array}$ & $\begin{array}{l}\text { PN140 (adult) } \\
\text { OFT } \\
\text { Elevated Zero Maze (EZM) } \\
\text { FST }\end{array}$ & $\begin{array}{l}\text { Male: } \\
\text { OFT - Fluoxetine exposure decreased centre crossing in } \\
\text { naïve offspring compared to maternally stressed offspring } \\
\text { (-50\%). } \\
\text { FST - decreased escape driven behaviour in maternally } \\
\text { stressed offspring regardless of treatment (-12\%). } \\
\text { EZM - no differences } \\
\text { Summary - In male offspring SSRI exposure in } \\
\text { combination with maternal stress decreased anxiety-like } \\
\text { behaviour. } \\
\text { Female: } \\
\text { FST - increased immobility (+100\%) } \\
\text { OFT and EZM - no differences } \\
\text { Summary - In females, SSRI exposure increased } \\
\text { depressive-like behaviour regardless of maternal stress. }\end{array}$ \\
\hline Rayen et al., (2011) & $\begin{array}{l}\text { Species/Strain } \\
\text { Sprague-Dawley Rats ( } \mathrm{n}=9-11 \\
\text { offspring/group) } \\
\text { Dose } \\
\text { Fluoxetine } 5 \mathrm{mg} / \mathrm{kg} \\
\text { Route and Duration } \\
\text { PN1 - PN21 Osmotic Minipumps } \\
\text { Stress (maternal depression model) } \\
\text { Restraint 3x daily under bright light for } \\
45 \text { minutes from GD15 - GD20. }\end{array}$ & $\begin{array}{l}\text { PN32 (adolescence) } \\
\text { OFT } \\
\text { FST }\end{array}$ & $\begin{array}{l}\text { FST - Increased immobility in offspring born of maternally } \\
\text { stressed dams (+150\%). } \\
\text { OFT - no difference } \\
\text { Summary - SSRI exposure reversed the decrease in } \\
\text { depressive-like behaviour observed in unexposed } \\
\text { maternally stressed offspring. }\end{array}$ \\
\hline
\end{tabular}




\begin{tabular}{|c|c|c|c|}
\hline $\begin{array}{l}\text { Francis-Olivier et al., } \\
\text { (2013) }\end{array}$ & $\begin{array}{l}\text { Species/Strain } \\
\text { Wistar Rat } \\
\text { Dose } \\
\text { Fluoxetine } 5 \mathrm{mg} / \mathrm{kg} \\
\text { Route and Duration } \\
\text { GD0 - PN21 Gavage }\end{array}$ & $\begin{array}{l}\text { PN35 (adolescence) and } \\
\text { PN75 (adult) } \\
\text { SPT } \\
\text { NSF }\end{array}$ & $\begin{array}{l}\text { NSF - decreased latency to feed at adolescence (-30\%) } \\
\text { SPT - no difference } \\
\text { Summary - SSRI exposure caused decreases in anxiety-like } \\
\text { and depressive like-behaviour in offspring at adolescence. }\end{array}$ \\
\hline $\begin{array}{l}\text { Smit-Rigter et al., } \\
\text { (2012) }\end{array}$ & $\begin{array}{l}\text { Species/Strain } \\
\text { C57BL/6 Mice (n/group not specified) } \\
\text { Dose } \\
\text { Fluoxetine } 0.6 \mathrm{mg} / \mathrm{kg} \\
\text { Route and Duration } \\
\text { GD8 - GD18 IP }\end{array}$ & $\begin{array}{l}\text { Unknown age of testing } \\
\text { NSF }\end{array}$ & $\begin{array}{l}\text { NSF - Increased latency to feed (+66\%) } \\
\text { Summary - SSRI exposure caused increases in anxiety-like } \\
\text { and depressive like-behaviour in offspring. }\end{array}$ \\
\hline \multicolumn{4}{|c|}{ Prenatal/maternal exposure and postnatal/pup exposure } \\
\hline $\begin{array}{l}\text { Sprowles et al., } \\
\text { (2016b) }\end{array}$ & $\begin{array}{l}\text { Species/Strain } \\
\text { Sprague-Dawley Rats ( } n=9-23 \\
\text { offspring/group) } \\
\text { Dose } \\
\text { Citalopram 10mg/kg } \\
\text { Route and Duration (Dams) }\end{array}$ & $\begin{array}{l}\text { PN60 (adult) } \\
\text { Straight Channel Swimming } \\
\text { (SCS) } \\
\text { Cincinnati Water Maze } \\
\text { (CWM) } \\
\text { MWM } \\
\text { OFT }\end{array}$ & $\begin{array}{l}\text { MWM - Increased latency to reach platform }(+40) \\
\text { OFT - decreased centre crossing }(-66 \% \text {, females only) } \\
\text { MB - increased burying of marbles (+140\%) } \\
\text { PPI - increased response amplitudes (day } 1,+280 \% \text {; day } 2 \text {, } \\
+110 \%) \\
\text { FST - decreased latency to first bout of immobility }(-100 \%)\end{array}$ \\
\hline
\end{tabular}




\begin{tabular}{|c|c|c|c|}
\hline & $\begin{array}{l}\text { GD6 - GD21 } 2 x \text { daily Subcutaneous } \\
\text { Injection (SC) } \\
\text { Route and Duration (Offspring) } \\
\text { PN1 - PN20 2x daily SC }\end{array}$ & $\begin{array}{l}\text { EZM } \\
\text { Marble Burying (MB) } \\
\text { PPI } \\
\text { SB } \\
\text { FST }\end{array}$ & $\begin{array}{l}\text { SCS, CWM, EZM and SB - no difference } \\
\text { Summary - SSRI exposed offspring had alterations in } \\
\text { cognition and increased anxiety- and depressive-like } \\
\text { behaviour. }\end{array}$ \\
\hline \multicolumn{4}{|c|}{ Postnatal/pup exposure } \\
\hline Lee and Lee (2012) & $\begin{array}{l}\text { Species/Strain } \\
\text { Wistar Rats ( } n=14-15 / \text { group) } \\
\text { Dose } \\
\text { Fluoxetine } 20 \mathrm{mg} / \mathrm{kg} \\
\text { Route and Duration } \\
\text { PNO - PN4 SC }\end{array}$ & $\begin{array}{l}\text { PN30 (adolescence) } \\
\text { OFT } \\
\text { EPM } \\
\text { RT }\end{array}$ & $\begin{array}{l}\text { OFT - decreased locomotor activity (-23\%) } \\
\text { RT - decreased latency to fall (-44\%) } \\
\text { EPM - no difference } \\
\text { Summary - SSRI exposed offspring had increased anxiety- } \\
\text { like behaviour, evident through decreased exploratory } \\
\text { behaviour and impaired motor function. }\end{array}$ \\
\hline $\begin{array}{l}\text { Ansorge et al., } \\
\text { (2004) }\end{array}$ & $\begin{array}{l}\text { Species/Strain } \\
\text { SERT Knockout Mice }(+/+)(+/-)(-/-) \\
\text { (n=13-27/group) } \\
\text { Dose } \\
\text { Fluoxetine } 10 \mathrm{mg} / \mathrm{kg} \\
\text { Route and Duration } \\
\text { PN4 - PN21 IP }\end{array}$ & $\begin{array}{l}\text { PN84 (adult) } \\
\text { OFT } \\
\text { EPM }\end{array}$ & $\begin{array}{l}\text { OFT - decreased distance travelled (-40\%), reduced total } \\
\text { ambulatory time }(-38 \%) \text { and vertical activity }(-75 \%) \\
\text { EPM - decreased entries into both arms }(-30 \%) \\
\text { NSF - increased latency to feed in }(+/-) \text { mice only }(+130 \%) \\
\text { SE - Increased latency to escape }(+150 \%) \\
\text { Summary - SSRI exposure increased anxiety- and } \\
\text { depressive-like behaviour evident through reduced } \\
\text { exploratory behaviours, increased latency to feed, and } \\
\text { increased latency to escape in SERT }(+/+) \text { and }(+/-)\end{array}$ \\
\hline
\end{tabular}




\begin{tabular}{|c|c|c|c|}
\hline & & & offspring. Had no effect on SERT (-/-) offspring. \\
\hline $\begin{array}{l}\text { Ansorge et al., } \\
\text { (2008) }\end{array}$ & $\begin{array}{l}\text { Species/Strain } \\
\text { SERT Knockout Mice }(+/+)(+/-) \\
\text { (n=32-65/group) } \\
\text { Dose } \\
\text { Fluoxetine } 10 \mathrm{mg} / \mathrm{kg} \\
\text { Desipramine } 10 \mathrm{mg} / \mathrm{kg} \\
\text { Citalopram } 10 \mathrm{mg} / \mathrm{kg} \\
\text { Clomipramine } 20 \mathrm{mg} / \mathrm{kg} \\
\text { Route and Duration } \\
\text { PN4 - PN21 IP }\end{array}$ & $\begin{array}{l}\text { PN84 (adult) } \\
\text { OFT } \\
\text { EPM } \\
\text { NSF } \\
\text { Novelty Induced } \\
\text { Hypophagia (NIH) } \\
\text { Shock Escape (SE) }\end{array}$ & $\begin{array}{l}\text { OFT - reduced ambulatory time (-18 to }-30 \%) \\
\text { EPM - reduced entries into either arms (-10 to }-22 \%) \\
\text { NSF - increased latency to feed ( }+60 \text { to }+45 \%) \\
\text { NIH - increased latency to drink ( }+83 \text { to }+100 \%) \\
\text { SE - increased latency to escape ( }+25 \text { to }+38 \%) \\
\text { Summary }- \text { SSRI exposed had increased anxiety- and } \\
\text { depressive-like behaviour and reduced exploratory } \\
\text { behaviour. }\end{array}$ \\
\hline Zheng et al., (2011) & $\begin{array}{l}\text { Species/Strain } \\
\text { GFP-transgenic mice and wild-type } \\
\text { C57 mice. (n/group not specified) } \\
\text { Dose } \\
\text { Fluoxetine }(10 \mathrm{mg} / \mathrm{kg}) \\
\text { Fluvoxamine }(10 \mathrm{mg} / \mathrm{kg}) \\
\text { Route and Duration } \\
\text { PN4 - PN21 IP }\end{array}$ & $\begin{array}{l}\text { PN91 (adult) } \\
\text { OFT }\end{array}$ & $\begin{array}{l}\text { OFT - decreased distance travelled (-37\%) } \\
\text { Summary - SSRI exposure increased anxiety-like } \\
\text { behaviour evident through decreased exploratory } \\
\text { behaviour. }\end{array}$ \\
\hline $\begin{array}{l}\text { Karpova et al., } \\
\text { (2009) }\end{array}$ & $\begin{array}{l}\text { Species/Strain } \\
\text { C57BL/6 Mice ( } \mathrm{n}=9-12 / \text { group) } \\
\text { Dose } \\
\text { Fluoxetine }(10 \mathrm{mg} / \mathrm{kg})\end{array}$ & $\begin{array}{l}\text { PN110 (adult) } \\
\text { Light-Dark Test (LDT) } \\
\text { OFT } \\
\text { FST }\end{array}$ & $\begin{array}{l}\text { LDT }- \text { reduction in rearing }(-42 \%) \text { and increased immobility } \\
(+11 \%) \\
\text { OFT }- \text { reduced rearing }(-30 \%) \text { increased immobility in } \\
\text { central arena }(+42 \%)\end{array}$ \\
\hline
\end{tabular}




\begin{tabular}{|c|c|c|c|}
\hline & $\begin{array}{l}\text { Route and Duration } \\
\text { PN4 - PN21 IP }\end{array}$ & & $\begin{array}{l}\text { FST - decreased immobility time (-38\%) } \\
\text { Summary - SSRI-exposed offspring had increased anxiety- } \\
\text { like behaviour but reduced depressive-like behaviour. }\end{array}$ \\
\hline Lee, (2009) & $\begin{array}{l}\text { Species/Strain } \\
\text { Wistar Rats ( } n=12-15 / \text { group) } \\
\text { Dose } \\
\text { Fluoxetine (10mg/kg) } \\
\text { Route and Duration } \\
\text { PNO - PN6 SC }\end{array}$ & $\begin{array}{l}\text { PN30 - } 35 \text { (adolescence) } \\
\text { HPT } \\
\text { Gap-Crossing Test (GCT) } \\
\text { OFT }\end{array}$ & $\begin{array}{l}\text { HPT - increased latency to first licking }(+110 \%) \\
\text { GCT - decreased crossable gap distance }(-36 \%) \\
\text { OFT - decreased total (-20\%) and central (-37\%) } \\
\text { ambulation and decreased rearing (-19\%) } \\
\text { Summary - SSRI-exposed offspring exhibited greater pain } \\
\text { thresholds. Impaired environmental perception (gap- } \\
\text { crossing test) and increased anxiety-like behaviour. }\end{array}$ \\
\hline $\begin{array}{l}\text { Rodriguez-Porcel et } \\
\text { al., (2011) }\end{array}$ & $\begin{array}{l}\text { Species/Strain } \\
\text { Long Evans Rats ( } n=12-22 / \text { group) } \\
\text { Dose } \\
\text { Fluoxetine }(5 \mathrm{mg} / \mathrm{kg}) \\
\text { Citalopram }(10 \mathrm{mg} / \mathrm{kg}) \\
\text { Bupropion }(15 \mathrm{mg} / \mathrm{kg}) \\
\text { Route and Duration } \\
\text { PN8 - PN21 2x daily SC }\end{array}$ & $\begin{array}{l}\text { PN25 - } 39 \text { (adolescence) } \\
\text { Locomotor Tone (LT) } \\
\text { Novel Object Approach } \\
\text { (NOA) } \\
\text { Juvenile Play (JP) } \\
\text { PN89 - } 184 \text { (adult) } \\
\text { Object-Conspecific } \\
\text { Preference (OCP) } \\
\text { SB }\end{array}$ & $\begin{array}{l}\text { Adolescence (PN25-39) } \\
\text { LT - increased immobility in response to tone (+180\%) } \\
\text { NOA - reduced time spent investigating the novel object (- } \\
33 \%) \text { in males } \\
\text { JP - reduced pinning (-82 to }-98 \%) \text { in males and boxing in } \\
\text { both male (-71 to }-80 \%) \text { and females (-71\%). } \\
\text { Adult (PN89-184) } \\
\text { OCP - reduced time spent investigating conspecific subject } \\
(-58 \%) \\
\text { SB - disrupted mounting behaviour } \\
\text { Summary - SSRI-exposure increased anxiety-like } \\
\text { behaviour and impaired social and sexual behaviour in } \\
\text { offspring. }\end{array}$ \\
\hline
\end{tabular}

Abbreviations: Flx = Fluoxetine; Flv = Fluvoxamine; GD = Gestational Day; PN = Postnatal Day; NG = Negative Geotaxis; OFT = Open Field Test; RT = Rotarod Test; $M W M=$ Morris Water Maze; EPM = Elevated Plus Maze; $P A=$ Passive Avoidance Test; $L R N=$ Locomotor Response to Novelty; FST = Forced Swim Test; $I R T=$ Intruder Resistant Test; HPT = Hot Plate Test; $P A T=$ Passive Avoidance Test; $P P I=$ Prepulse Inhibition Test; $S B=$ Social Behaviour; $N S F=$ Novelty-Suppressed Feeding; $C P A=$ Conditioned Place Aversion; EPMS = Elevated Plus Maze after Stress; SPT = Sucrose Preference Test; $A S P=A d o l e s c e n t$ Social Play; $A d S P=$ Adult Social Play; SeB = Sexual Behaivour; IP = Intraperitoneal; SC = Subcutaneous; HL = Horizontal Ladder; FC = Fear Conditioning; EZM 
= Elevated Zero Maze; CWM = Cincinnati Water Maze; MB = Marble Burying Test; SCS = Straight Channel Swimming; NIH = Novelty Induced Hypophagia SE = Shock Escape Test; LDT = Light-Dark Test; GCT = Gap-Crossing Test; LT = Locomotor Tone; NOA = Novel Object Approach; JP = Juvenile Play; OCP = Object Conspecific Recognition 
There is mounting evidence from human and animal studies to suggest neurobehavioural alterations in offspring exposed to SSRIs (Tables 1 and 3). Understanding the biological foundations of such exposure might help elucidate causative mechanisms underlying behavioural alterations and increased risk profiles, and assists in the development of appropriate preventative strategies.

As SSRIs bind to and inhibit SERT, resulting in increased synaptic levels of serotonin, it is reasonable to hypothesise that SSRI exposure could lead to altered development of aspects of the serotonin system. Several studies have focused on the effect of developmental SSRI exposure on the developmental expression of SERT. Specifically, it was reported that SERT densities at adolescence (PN28) were significantly increased in the hippocampus, amygdala and lateral hypothalamus, decreased in the dorsomedial hypothalamus and substantia nigra, and unchanged in the raphe nuclei, of fluoxetine-exposed rodent offspring (CabreraVera and Battaglia, 1998). The findings indicated brain region specific changes and a particular vulnerability of the limbic system (Cabrera-Vera and Battaglia, 1998). Interestingly, the same study noted no significant differences in SERT densities between exposed and control groups at adulthood (PN70), suggesting that the effects of developmental SSRI exposure on SERT are transient in nature and become negligible in later life (Cabrera-Vera and Battaglia, 1998). On the contrary another study reported reductions in SERT expression in the raphe nucleus that persisted during adolescence (PN20) and adulthood (PN90) following exposure to fluoxetine (Noorlander et al., 2008). The same study also reported increases in anxiety- and depressive-like behaviour at both PN20 and PN90 in offspring exposed to SSRIs in-utero, providing a potential behavioural translation to the alterations in SERT expression (Noorlander et al., 2008). Another study assessing serotonergic neurons in the raphe nucleus of offspring at PN56 reported marked reductions in neuronal number and axonal terminals as a result of SSRI exposure (Silva et al., 2010). The contrast in findings in the raphe nucleus between these studies (Cabrera-Vera and Battaglia, 1998 and Noorlander et al., 2008) may be attributed to the use of different species (rat vs. mouse) as well as different drug doses and administration methods $(10 \mathrm{mg} / \mathrm{kg}$ s.c. vs. $0.8 \mathrm{mg} / \mathrm{kg}$ i.p. fluoxetine). Interestingly, a high maternal fluoxetine dosage did not produce longer lasting changes in SERT expression in the brain of offspring (Cabrera-Vera and Battaglia, 1998), which seems paradoxical but may allude to a greater influence of the drug 
administration method used in these studies. Accordingly, unlike subcutaneous, the pharmacokinetics of intraperitoneal injections parallels those administered orally given that they are absorbed through the mesenteric vessels and undergo first pass metabolism by the liver (Turner et al., 2011), and could result in a greater ratio of active metabolite to parent drug.

Taken together, it may be suggested that SERT expression is altered through a) decreased serotoninergic neurons at their origin (raphe nucleus) and hence decreased SERT expression, and/or b) alterations in serotonergic afferents to areas including the hippocampus and the subsequent altered expression of SERT, or c) the down/up-regulation of SERT in response to increased extracellular serotonin. Surprisingly, given the effect of SSRIs on the serotonergic system, there have been no studies to-date that have assessed the potential alterations to serotonergic receptors or associated signalling. Considering that SERT knock-out $(\mathrm{KO})$ rodents have shown reduced $5 \mathrm{HT}_{1 \mathrm{~A}}$ receptor binding in the raphe, hypothalamus, amygdala and septum ( $\mathrm{Li}$ et al., 2000), and increased $5 \mathrm{HT}_{2 \mathrm{~A} / 2 \mathrm{C}}$ receptor binding in the hypothalamus and amygdala (Li et al., 2003), this is clearly an area that warrants further investigation.

Given the neurotrophic role of serotonin during neurodevelopment (Gaspar et al., 2003), animal studies have also focused on the effects of developmental SSRI exposure on dendritic and neuronal mapping, and markers of neurogenesis, growth and development in offspring (Table 4). All studies report significant cellular alterations to some extent with varying SSRI exposure duration, dosage and exposure time points (Lee, 2009; Lee and Lee, 2012; Silva et al., 2010; Smit-Rigter et al., 2012; Swerts et al., 2010; Zheng et al., 2011). Exposing embryos to SSRIs during gestation induced significant morphological alterations, such as a decrease in neuronal number in the foetal frontal lobe at GD21 following $10 \mathrm{mg} / \mathrm{kg}$ fluoxetine treatment on GD9, 10 and 11 (Swerts et al., 2010). This study provides clear evidence of neuronal alterations in exposed offspring; however, examination of any potentially permanent alterations from birth to adulthood is required. Another study assessed pyramidal neuronal complexity (quantified by measuring dendritic branching and length) throughout adolescence to adulthood and reported a significant reduction in complexity following administration of $0.6 \mathrm{mg} / \mathrm{kg} /$ day fluoxetine to dams during GD8 - GD18 
(Smit-Rigter et al., 2012). The study provided evidence to suggest alterations caused by SSRI exposure persist to adulthood.

As discussed previously, a limited number of animal studies assess the effects of developmental SSRI exposure in clinically relevant models. Several recent studies have assessed the effects of SSRI exposure on the neurobiology of offspring using a model of maternal adversity by subjecting dams to stress (Boulle et al., 2016b, 2016a; Rayen et al., 2011). Although varied in methodology, these studies collectively show significant influences of SSRI exposure in animal models of stress (Table 4). One study reported a decrease in hippocampal neurogenesis and proliferation, and increase in depressive-like behaviour in adolescent offspring exposed to maternal stress (Rayen et al., 2011). The same study noted that these findings were corrected when the offspring were also exposed to maternal SSRI treatment (Rayen et al., 2011), suggesting that SSRI-exposure has the potential to reverse the negative effects of maternal depression on offspring, at least in relation to hippocampal neurogenesis. It has been widely suggested that the anti-depressive characteristics of SSRIs occurs via downstream mechanisms by increasing BDNF expression and subsequent neurogenesis (Martinowich and Lu, 2007). In contrast to this notion, one study assessing SSRI-exposure during development showed reduced levels of hippocampal BDNF mRNA expression in male and female offspring (Boulle et al., 2016a, 2016b). However, when examined in a model of maternal adversity, it was shown that the SSRI exposure corrected an observable increase in hippocampal BDNF induced by maternal stress in female offspring; while in the males, exposure to maternal stress alone or in combination with fluoxetine caused no effect (Boulle et al., 2016b). These sex-specific findings highlight the need for a greater focus on assessing the influence of sex on SSRI exposure and outcomes of maternal adversity. 
Table 4: Effects of maternal antidepressant administration on biological measures in exposed offspring: evidence from animal studies.

\begin{tabular}{|c|c|c|c|}
\hline $\begin{array}{l}\text { Study (Shaded studies } \\
\text { indicates those } \\
\text { implementing models } \\
\text { of maternal } \\
\text { depression/adversity). }\end{array}$ & Species, Strain, Drug Dose, Route and Duration & Analyses & Main Findings \\
\hline \multicolumn{4}{|c|}{ Prenatal/maternal exposure } \\
\hline Fornaro et al., (2007) & $\begin{array}{l}\text { Species/Strain } \\
\text { Sprague-Dawley rat dams. (n=9 to 11/group) } \\
\text { Dose } \\
\text { Fluoxetine (10mg/kg) } \\
\text { Route and Duration } \\
\text { Oral gavage daily to dams from GD11 to GD21 }\end{array}$ & $\begin{array}{l}\text { Serotonin concentrations in } \\
\text { Placenta and foetal lungs } \\
\text { Rat foetuses were collected } \\
\text { via caesarean section on } \\
\text { GD21 }\end{array}$ & $\begin{array}{l}\text { - Prenatal FLX exposure significantly reduced } \\
\text { (-38\%) placental tissue serotonin content. Did } \\
\text { not alter lung serotonin content. }\end{array}$ \\
\hline $\begin{array}{l}\text { Noorlander et al., } \\
\text { (2008) }\end{array}$ & $\begin{array}{l}\text { Species/Strain } \\
\text { Mice (C57BI/6-Jlco) ( } n=3-6 / \text { group) } \\
\text { Dose } \\
\text { Fluoxetine }(0.3,0.6 \text { or } 0.8 \mathrm{mg} / \mathrm{kg} \text { ). } \\
\text { Route and Duration } \\
\text { I.P. injection daily to dams from GD8 to GD18. }\end{array}$ & $\begin{array}{l}\text { Dorsal raphe nucleus } \\
\text { examined via } \\
\text { autoradiography for SERT } \\
\text { binding (PN20 and PN90) }\end{array}$ & $\begin{array}{l}\text { - Significant decreases at PN20 (-40\%) and } \\
\text { PN90 (-53\%) in SERT binding in the raphe } \\
\text { nucleus after prenatal exposure to FLX } \\
\text { compared to controls (dose-dependent } \\
\text { exposure). }\end{array}$ \\
\hline
\end{tabular}




\begin{tabular}{|c|c|c|c|}
\hline $\begin{array}{l}\text { Cabrera-Vera \& } \\
\text { Battaglia (1998) }\end{array}$ & $\begin{array}{l}\text { Species/Strain } \\
\text { Sprague-Dawley Dams } \\
\text { ( } \mathrm{n}=7 / \mathrm{group}) \\
\text { Dose } \\
\text { Fluoxetine }(10 \mathrm{mg} / \mathrm{kg}) \\
\text { Route and Duration } \\
\text { S.C. injection daily to dams from GD13 to GD20 }\end{array}$ & $\begin{array}{l}\text { PN28 and PN70 } \\
\text { Cortex, hippocampus, } \\
\text { septum, amygdala, basal } \\
\text { ganglia and raphe nucleus - } \\
\text { autoradiography for SERT } \\
\text { binding. }\end{array}$ & $\begin{array}{l}\text { PN28 Following prenatal FLX exposure } \\
\text { - Significant increases in SERT densities in the } \\
\text { CA2 and CA3 areas of the hippocampus (+47\% } \\
\text { and +38\% respectively). } \\
\text { - Significant increases in SERT densities in } \\
\text { basolateral (+32\%) and medial (+44\%) } \\
\text { amygdaloid nuclei and lateral hypothalamus } \\
\text { (+21\%) of offspring compared to controls. } \\
\text { - Significant reductions in SERT densities in } \\
\text { dorsomedial hypothalamus (-21\%) and } \\
\text { substantia nigra (-19\%) } \\
\text {-Nil significant differences in SERT densities in } \\
\text { raphe nucleus } \\
\text { PN70 Following prenatal FLX exposure } \\
\text { - nil significant differences in SERT densities in } \\
\text { any examined brain regions compared to } \\
\text { control }\end{array}$ \\
\hline $\begin{array}{l}\text { Female offspring } \\
\text { study } \\
\text { Boulle et al., (2016a) }\end{array}$ & $\begin{array}{l}\text { Species/Strain } \\
\text { Sprague-Dawley Dams } \\
\text { ( } n=7 / \text { group) } \\
\text { Groups } \\
\text { Prenatal stress + VEH } \\
\text { Prenatal stress + FLX } \\
\text { Control + VEH } \\
\text { Control + FLX } \\
\text { Dose }\end{array}$ & $\begin{array}{l}\text { Offspring (PN168) } \\
\text { Hippocampus } \\
\text { - Quantitative reverse } \\
\text { transcriptase PCR (qRT-PCR), } \\
\text { analyses of genes associated } \\
\text { with BDNF/TrKB signalling } \\
\text { pathway } \\
\text { - Chromatin } \\
\text { immunoprecipitation (ChIP), }\end{array}$ & $\begin{array}{l}\text { Female } \\
\text { - Significant decreases in hippocampal BDNF } \\
\text { exon IV mRNA levels in FLX-exposed offspring } \\
\text { (-10\% non-stressed group; }-20 \% \text { stressed } \\
\text { group) } \\
\text { - Significant negative correlation ( } r=-0.33, p \\
=0.02 \text { ) between hippocampal BDNF exon IV } \\
\text { mRNA levels and immobility in the forced } \\
\text { swim test. }\end{array}$ \\
\hline
\end{tabular}




\begin{tabular}{|c|c|c|c|}
\hline & $\begin{array}{l}\text { Fluoxetine }(5 \mathrm{mg} / \mathrm{kg} \text { ) } \\
\text { Route and Duration } \\
\text { Osmotic minipumps from PN1 to PN21. } \\
\text { Stress (exposure to confinement and bright } \\
\text { light for } 45 \mathrm{~min} \text { ) induced on GD14 to assigned } \\
\text { dams, occurring } 3 x \text { daily until end of pregnancy. }\end{array}$ & $\begin{array}{l}\text { quantification of fragments } \\
\text { of promoter regions of } \\
\text { target genes in BDNF/TrKB } \\
\text { signalling pathway }\end{array}$ & $\begin{array}{l}\text { Male } \\
\text { - Significant decreases in BDNF IV (-20\%) and } \\
\text { TrKB (-40\%) mRNA expression in the } \\
\text { hippocampus of FLX-exposed offspring. } \\
\text { - Significant decreases in hippocampal BDNF } \\
\text { mRNA (-20\%) expression of prenatally } \\
\text { stressed subjects regardless of treatment. }\end{array}$ \\
\hline Morrison et al., (2004) & $\begin{array}{l}\text { Species/Strain } \\
\text { Sheep ewe ( } \mathrm{n}=7-8 / \text { group }) \\
\text { Dose } \\
\text { Fluoxetine }(98.5 \mu \mathrm{g} / \mathrm{kg}) \\
\text { Route and Duration } \\
\text { Polyvinyl catheters to dam for } 8 \text { days, } \\
\text { commencement ranged from GD118- } 122 \pm 4-5 \\
\text { days. }\end{array}$ & $\begin{array}{l}\text { Foetal blood (sampled daily } \\
\text { during infusion period, } 8 \\
\text { days). } \\
\text { - ACTH } \\
\text { - Cortisol } \\
\text { - FLX }\end{array}$ & $\begin{array}{l}\text { - Significant increase }(+115 \%) \text { in FLX exposed } \\
\text { foetal plasma cortisol concentrations on } \\
\text { infusion day(s) } 6,7 \text { and } 8 \text {. } \\
\text { - Significant increase }(+102 \%) \text { foetal plasma } \\
\text { ACTH concentrations on infusion day } 7 \text { in FLX } \\
\text { exposed }\end{array}$ \\
\hline Rayen et al., (2011) & $\begin{array}{l}\text { Species/Strain } \\
\text { Sprague-Dawley ( } \mathrm{n}=9-11 / \text { group) } \\
\text { Groups } \\
\text { Prenatal stress + VEH } \\
\text { Prenatal stress + FLX } \\
\text { Control + VEH } \\
\text { Control + FLX } \\
\text { Dose } \\
\text { Fluoxetine (5mg/kg) } \\
\text { Route and Duration }\end{array}$ & $\begin{array}{l}\text { Immunohistochemistry } \\
\text { (PN42) } \\
\text { - Hippocampus and dentate } \\
\text { gyrus number of } \\
\text { proliferating cells and } \\
\text { immature neurons. }\end{array}$ & $\begin{array}{l}\text { - FLX exposure significantly reversed the } \\
\text { decrease in hippocampal cell proliferation } \\
\text { and hippocampal neurogenesis in prenatally } \\
\text { stressed offspring to levels comparable to } \\
\text { control. }\end{array}$ \\
\hline
\end{tabular}




\begin{tabular}{|c|c|c|c|}
\hline & Osmotic minipumps to dams from PN1 to PN39. & & \\
\hline $\begin{array}{l}\text { Smit-Rigter et al., } \\
\text { (2012) }\end{array}$ & $\begin{array}{l}\text { Species/Strain } \\
\text { Mice (C57/BL6J) } \\
\text { Dose } \\
\text { Fluoxetine }(0.6 \mathrm{mg} / \mathrm{kg}) \\
\text { Route and Duration } \\
\text { I.P. injections to dams from GD8 - GD18. }\end{array}$ & $\begin{array}{l}\text { Offspring brains collected to } \\
\text { determine complexity of } \\
\text { dendritic tree of layer } 2 / 3 \\
\text { pyramidal neurons in the } \\
\text { somatosensory cortex at } \\
\text { three ages (PN6-9, PN60 and } \\
\text { PN>365). } \\
\text { Complexity of dendritic tree } \\
\text { was quantified using the } \\
\text { Dendritic Complexity Index } \\
\text { (DCI), which takes into } \\
\text { consideration dendritic } \\
\text { branching and dendritic } \\
\text { length. }\end{array}$ & $\begin{array}{l}\text { - Significant reduction ( } 50 \% \text { ) in complexity } \\
\text { of } 2 / 3 \text { pyramidal neurons of fluoxetine } \\
\text { exposed animals. Reduction in complexity was } \\
\text { evident at all life stages (PN6-9, PN60, } \\
\text { PN>365) }\end{array}$ \\
\hline
\end{tabular}




\begin{tabular}{|c|c|c|c|}
\hline \multicolumn{4}{|c|}{ Postnatal/pup exposure } \\
\hline Silva et al., (2010) & $\begin{array}{l}\text { Species/Strain } \\
\text { Wistar Rat pups ( } \mathrm{n}=5 / \text { group) } \\
\text { Dose } \\
\text { Fluoxetine (10mg/kg) } \\
\text { Route and Duration } \\
\text { S.C. injections daily to pups from PN1 to PN21 }\end{array}$ & $\begin{array}{l}2 \text { months of age ( PN56) } \\
\text { subject brains collected for } \\
\text { morphometric analysis of } \\
5 \mathrm{HT} \text { neurons in the dorsal } \\
\text { (DR) and median (MnR) } \\
\text { raphne nuclei, and } \\
\text { hippocampal dentate gyrus } \\
\text { (DG). } \\
\text { Morphometric parameters } \\
\text { of serotonergic neurons } \\
\text { - Perimeter (PER) } \\
\text { - Maximum, minimum and } \\
\text { median diameters (Dmax, } \\
\text { Dmin and Dmed). }\end{array}$ & $\begin{array}{l}\text { - Significant reduction in neuron number of } \\
\text { the DR (-26\%), and reduced } 5 \mathrm{HT} \text { terminals (- } \\
63 \%) \text { in the DG of FLX exposed compared to } \\
\text { vehicles. } \\
\text { - Significant reduction in all morphometric } \\
\text { parameters of serotonergic neurons. } \\
\text { DR } \\
- \text { Perikaryal area (-18\%), Dmax (-9.6\%), Dmin (- } \\
17 \%) \text {, Perikaryal perimeter (-9.6\%). } \\
\text { MnR } \\
- \text { Perikaryal area (-23\%), Dmax (-13\%), Dmin (- } \\
10 \%), \text { Dmed (-14\%) Perikaryal perimeter (- } \\
13.5 \%) \text {. }\end{array}$ \\
\hline Lee (2009) & $\begin{array}{l}\text { Species/Strain } \\
\text { Wistar Rat Pups ( } n=36 \text { to 42/group) } \\
\text { Dose } \\
\text { Fluoxetine }(10 \mathrm{mg} / \mathrm{kg}) \\
\text { Route and Duration } \\
\text { S.C. injections daily to pups from PNO to PN6. }\end{array}$ & $\begin{array}{l}\text { PN7 and PN35 } \\
\text { Dil Labelling of } \\
\text { Thalamocortical Afferents } \\
\text { (somatosensory cortex) } \\
\text { Golgi-Cox impregnation } \\
\text { (somatosensory cortex) }\end{array}$ & $\begin{array}{l}\text { - Significant reduction }(-51 \%) \text { in number of } \\
\text { terminal tips of Thalamocortical afferent } \\
\text { arbors } \\
\text { - Significant reduction in dendritic field (- } \\
27 \%) \text {, shorter dendritic length }(-20 \%) \text { and } \\
\text { fewer terminal endings }(-20 \%) \text { in FLX exposed } \\
\text { compared to vehicle. } \\
\text { - Significant reduction in dendritic spines of } \\
\text { the } 2^{\text {nd }}(-43 \%), 3^{\text {rd }}(-42 \%) \text { and } 4^{\text {th }}(-40 \%) \\
\text { dendritic orders. }\end{array}$ \\
\hline Lee \& Lee (2011) & $\begin{array}{l}\text { Species/Strain } \\
\text { Wistar Rat Pups ( } n=7 \text { to 9/group) } \\
\text { Dose }\end{array}$ & $\begin{array}{l}\text { PN35 } \\
\text { Immunochemistry } \\
\text { - cerebellum (Purkinje cells) } \\
\text { Golgi-Cox Impregnation }\end{array}$ & $\begin{array}{l}\text {-Significant reduction in bifurcation nodes (- } \\
25 \%) \text {, terminals }(-25 \%) \text { and dendritic length (- } \\
38 \%) \text { of medium spiny striatal neurons and }\end{array}$ \\
\hline
\end{tabular}




\begin{tabular}{|c|c|c|c|}
\hline & $\begin{array}{l}\text { Fluoxetine }(20 \mathrm{mg} / \mathrm{kg}) \\
\text { Dose and Duration } \\
\text { S.C. injections daily to pups from PNO to PN4 }\end{array}$ & $\begin{array}{l}\text { - Striatum (dendritic } \\
\text { structure) } \\
\text { - Layer } 5 \text { pyramidal neurons } \\
\text { of primary motor cortex }\end{array}$ & $\begin{array}{l}\text { Layer } 5 \text { pyramidal M1 neurons. } \\
\text { - No significant differences in Purkinje cell } \\
\text { density and soma size between treatment } \\
\text { groups }\end{array}$ \\
\hline Zheng et al., (2011) & $\begin{array}{l}\text { Species/Strain } \\
\text { Male GFP-Transgenic mice or wild-type C57 } \\
\text { mice } \\
\text { Dose } \\
\text { Fluoxetine or Fluvoxamine }(10 \mathrm{mg} / \mathrm{kg}) \\
\text { Route and Duration } \\
\text { I.P. injections daily to pups from PN4 to PN21 }\end{array}$ & $\begin{array}{l}\text { Confocal imaging of } \\
\text { hippocampus neuronal } \\
\text { development - spinal } \\
\text { densities of CA1 neurons } \\
\text { were assessed at PN22 } \\
\text { (adolescence) and PN90 } \\
\text { (adult) stages. }\end{array}$ & $\begin{array}{l}\text { - Significant reduction (-10\%) in spine density } \\
\text { of basal dendrites at PN22 of SSRI exposed } \\
\text { groups } \\
\text { - Significant reduction }(-16 \%) \text { in spine density } \\
\text { of apical dendrites at PN22 of those exposed } \\
\text { to fluvoxamine } \\
\text { - Significant increase (+15\%) in spine density } \\
\text { of basal dendrites at PN90 of SSRI exposed } \\
\text { groups } \\
\text { - Significant increase (+13\%) in spine density } \\
\text { of apical dendrites at PN90 of those exposed } \\
\text { to fluoxetine. }\end{array}$ \\
\hline
\end{tabular}

Abbreviations: $F L X=$ fluoxetine, $D A=$ dopamine, $N E=$ norephinephrine, $5-H T=5$-hydroxytryptamine receptors, $D O P A C=3,4-$ dihydroxyphenylacetic acid, 5-HIAA = 5-hydroxyindoleacetic acid, HVA = homovanillic acid, s.c. = subcutaneously, SERT = serotonin transporter, GD = gestational day, $P_{C o 2}=$ partial pressure of carbon dioxide, $P_{O_{2}}=$ partial pressure of oxygen, $A C T H=$ adrenocorticotropic hormone, i.p. $=$ intraperitoneal, $C B G=$ corticosteroid binding

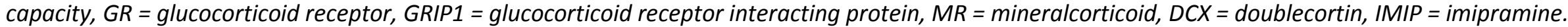




\subsection{Considerations for Animal Studies}

Animal studies, whilst being a step away from the clinic, have begun to address the question of whether the reported adverse effects of maternal SSRI treatment on offspring are the result of SSRI exposure or a response to innate maternal depression and/or adversity. However, a number of limitations and challenges arise when translating preclinical findings to the clinical scenario. Firstly, with the exception of studies that model maternal depression using environmental stressors, most studies administer SSRIs to healthy dams, which does not represent the clinical scenario. Indeed, the very presence of maternal depression, a disorder characterized by an underlying serotonergic pathology, could influence the effects of maternal SSRI exposure on offspring. One current animal model of depression, the Wistar-Kyoto rat (WKY), exhibits serotonergic and behavioural abnormalities similar to human depressive disorder (Arango et al., 2001; Lemos et al., 2011; Paré, 1994; Pare and Tejani-Butt, 1996; Quan-Bui et al., 1984; Scholl et al., 2010; Sullivan et al., 2006; Zhang et al., 2005) and could provide an invaluable tool for investigating the effects of SSRI exposure in a more clinically relevant setting. For example, the WKY exhibits increased anxiety- and depressive-like behaviour, decreased basal serotonin and 5HIAA concentrations, decreased SERT density in hippocampal and cortical brain regions, decreased $5 \mathrm{HT}_{1 \mathrm{a}}$ receptor density and a reduction in the serotonin rate limiting enzyme, tryptophan hydroxylase; all of which have been reported in clinical cases of MDD (Arango et al., 2001; Lemos et al., 2011; Paré, 1994; Pare and Tejani-Butt, 1996; Quan-Bui et al., 1984; Scholl et al., 2010; Sullivan et al., 2006; Zhang et al., 2005). Acknowledging that MDD is not characterised by abnormalities in the serotonergic system alone, these serotonergic alterations in both clinical cases of MDD and the WKY rat could underpin significant differences in response to SSRI exposure compared to the response observed in otherwise healthy subjects. Furthermore, the few animal studies modelling maternal adversity have shown that maternal SSRI treatment differentially affects offspring neurodevelopment and behaviour compared to subjects born of dams absent of adversity (Boulle et al., 2016a, 2016b; Kiryanova et al., 2016; Rayen et al., 2011). Overall, further research utilising appropriate models of depression or adversity are required in order to determine the effects of maternal SSRI exposure on offspring in a clinically relevant setting. 
The second limitation to consider when interpreting evidence from animal models is the variation in SSRI dosages and treatment duration between studies. Fluoxetine, which appears to be the SSRI of choice for animal studies, ranges in dosages from $0.3 \mathrm{mg} / \mathrm{kg}$ to $25 \mathrm{mg} / \mathrm{kg}$ in animal studies whilst in the clinic, daily fluoxetine doses of $20-80 \mathrm{mg}$ are commonly prescribed (Beasley et al., 2000). Further investigation into the dose range that is clinically relevant for rodent studies is required. The critical neurodevelopmental time period which SSRI exposure confers the greatest changes are also unknown. As such, variance in the timing and duration of SSRI exposure during and after gestation remains a major difference in methods between rodent studies (Tables 3 and 4). As previously discussed animal studies can be divided into those that administer SSRIs maternally, thereby indirectly exposing offspring (similar to the clinical scenario), or those that directly administer SSRIs to offspring in early life. Neurodevelopmental milestones occurring in rodents between PN1 - PN10 are equivalent to those occurring during 23 - 40 weeks gestation in humans (Semple et al., 2013). Thus, postnatal exposure in rodents represents developmental exposure during the third trimester in humans only and should be interpreted as such. It is still unclear from human studies whether there are periods either during pregnancy or after that confer greater risks associated with SSRI exposure. Further animal studies are required to examine the time-dependent effects of developmental SSRI exposure on offspring.

Finally, animal studies have been useful in the assessment of the molecular effects of SSRI exposure on offspring; however, they have largely focused on the serotonergic system and neuronal topography, with evidence suggesting that SSRI exposure can produce alterations to serotonergic (Raphe) neuronal number, SERT densities and neuronal/dendritic mapping in offspring (see Table 4.). Further examination of other neurotransmitter systems implicated in the neurobiology and pathology of various developmental neuropsychiatric disorders is required. Human studies have suggested an increased risk of ADHD, ASD and depression in SSRI-exposed offspring; disorders which are characterized by gross alterations in glutamatergic, GABAergic and neurotrophic signalling (Brambilla et al., 2003; Castrén and Rantamäki, 2010; Coghlan et al., 2012; Dölen et al., 2007; Duman et al., 2000; Dwivedi et al., 2003; Hashemi et al., 2016; Hashimoto, 2010; Homberg et al., 2014; Kim et al., 1982; Knable et al., 2004; Küçükibrahimoğlu et al., 2009; Lin and Sibille, 2013; Mitani et al., 2006; 
Sanacora et al., 2012). Indeed, the purported increased risk of inducing developmental disorders associated with maternal SSRI exposure could be related to the perturbed development of a range of systems, not only serotonin itself. Investigation of other neurotransmitter and neurotrophic systems would provide valuable insight into broader alterations caused by maternal SSRI exposure and form a basis for future studies.

\section{Concluding Remarks}

In conclusion, the current body of evidence suggests that maternal SSRI treatment may cause perturbations to the neurobiology, behaviour and ultimately risk for neurodevelopmental disorders in exposed offspring. However, conflicting findings do persist and the evidence summarised in the current review regarding the safety of SSRI use during pregnancy or whilst breast feeding is far from conclusive. Evidence from human studies suggest that SSRI exposure during neurodevelopment may be associated with an increased risk for neurodevelopmental disorders, such as ADHD and ASD, and mood disorders including depression; however, these studies are often confounded by the presence of the underlying maternal psychopathology. Difficulties in quantifying or accounting for the symptom severity of the maternal psychopathology are often inherent to clinical studies, and since SSRI treatment could be phenotypically masking symptoms, the findings warrant careful consideration. Furthermore, given that untreated maternal depression and adversity themselves are associated with an increased risk for neurodevelopmental disorders; maternal SSRI use could in fact be a marker of symptom severity of the underlying mood disorder, which itself contributes to the reported risk. Contrary to this notion, preclinical studies have reported alterations in behaviour and neurobiology in offspring as the result of developmental SSRI-exposure in otherwise healthy animals, suggesting that SSRI exposure can cause long lasting perturbations to neurodevelopment, irrespective of the innate maternal mood disorder. Although valuable in assessing the effects of developmental SSRIexposure in isolation, these studies are limited by the fact that they use healthy or naïve animals otherwise free of any underlying psychopathology. In the clinic, SSRI treatment and an underlying mood disorder occur in combination and it may be that the underlying mood disorder confers a degree of resistance (or exacerbation), or at least influences the effects of SSRI-exposure on offspring. The pervading question that remains unanswered is: if SSRI use 
does increase the risk of neurodevelopmental disorders in offspring, which of the two factors - the underlying maternal psychopathology or the SSRI treatment - has a greater influence on this risk. Further research utilizing models of depression is required in order to clarify the answer to this question in a manner that truly discerns the effects of SSRIexposure from the innate maternal mood disorder on offspring neurodevelopment and risk for associated disorders. Considering the number of women prescribed ADDs during pregnancy, further research into this area is warranted. 


\section{Acknowledgment:}

This review has been conducted with the support of the Australian Government Research Training Program Scholarship awarded to S.J.M and the University of Wollongong Faculty of Science, Medicine and Health Target Grant to K.A.N.

\section{Conflict of Interest:}

The authors have no conflicting financial interests to declare.

\section{References:}

Ansorge, M.S., Morelli, E., Gingrich, J.A., 2008. Inhibition of serotonin but not norepinephrine transport during development produces delayed, persistent perturbations of emotional behaviors in mice. J. Neurosci. Off. J. Soc. Neurosci. 28, 199-207. doi:10.1523/JNEUROSCI.3973-07.2008

Ansorge, M.S., Zhou, M., Lira, A., Hen, R., Gingrich, J.A., 2004. Early-Life Blockade of the 5-HT Transporter Alters Emotional Behavior in Adult Mice. Science 306, 879-881. doi:10.1126/science.1101678

Arango, V., Underwood, M.D., Boldrini, M., Tamir, H., Kassir, S.A., Hsiung, S., Chen, J.J.-X., Mann, J.J., 2001. Serotonin 1A Receptors, Serotonin Transporter Binding and Serotonin Transporter mRNA Expression in the Brainstem of Depressed Suicide Victims. Neuropsychopharmacology 25, 892-903. doi:10.1016/S0893-133X(01)00310-4

Arolt, V., Peters, M., Erfurth, A., Wiesmann, M., Missler, U., Rudolf, S., Kirchner, H., Rothermundt, M., 2003. S100B and response to treatment in major depression: a pilot study. Eur. Neuropsychopharmacol. J. Eur. Coll. Neuropsychopharmacol. 13, 235-239.

Ashman, S.B., Dawson, G., Panagiotides, H., Yamada, E., Wilkinson, C.W., 2002. Stress hormone levels of children of depressed mothers. Dev. Psychopathol. 14, 333-349.

Austin, M.-P., Karatas, J.C., Mishra, P., Christl, B., Kennedy, D., Oei, J., 2013. Infant neurodevelopment following in utero exposure to antidepressant medication. Acta Paediatr. 102, 1054-1059. doi:10.1111/apa.12379

Bairy, K.L., Madhyastha, S., Ashok, K.P., Bairy, I., Malini, S., 2006. Developmental and Behavioral Consequences of Prenatal Fluoxetine. Pharmacology 79, 1-11. doi:10.1159/000096645

Banerjee, E., Sinha, S., Chatterjee, A., Gangopadhyay, P.K., Singh, M., Nandagopal, K., 2006. A familybased study of Indian subjects from Kolkata reveals allelic association of the serotonin transporter intron-2 (STin2) polymorphism and attention-deficit-hyperactivity disorder (ADHD). Am. J. Med. Genet. B Neuropsychiatr. Genet. 141B, 361-366. doi:10.1002/ajmg.b.30296

Beasley, C.M., Nilsson, M.E., Koke, S.C., Gonzales, J.S., 2000. Efficacy, adverse events, and treatment discontinuations in fluoxetine clinical studies of major depression: a meta-analysis of the 20$\mathrm{mg} /$ day dose. J. Clin. Psychiatry 61, 722-728.

Bellissima, V., Visser, G.H.A., Ververs, T.F., Bel, F. van, Termote, J.U.M., Heide, M. van der, Gazzolo, D., 2015. Antenatal Maternal Antidepressants Drugs Affect S100B Concentrations in FetalMaternal Biological Fluids. CNS Neurol. Disord. Drug Targets 14, 49-54. 
Bleich, A., Brown, S.-L., Kahn, R., Praag, H.M. van, 1988. The Role of Serotonin in Schizophrenia. Schizophr. Bull. 14, 297-315. doi:10.1093/schbul/14.2.297

Bonnin, A., Goeden, N., Chen, K., Wilson, M.L., King, J., Shih, J.C., Blakely, R.D., Deneris, E.S., Levitt, P., 2011. A transient placental source of serotonin for the fetal forebrain. Nature 472, 347350. doi:10.1038/nature09972

Bonnin, A., Torii, M., Wang, L., Rakic, P., Levitt, P., 2007. Serotonin modulates the response of embryonic thalamocortical axons to netrin-1. Nat. Neurosci. 10, 588-597. doi:10.1038/nn1896

Boukhris, T., Sheehy, O., Mottron, L., Bérard, A., 2016. Antidepressant Use During Pregnancy and the Risk of Autism Spectrum Disorder in Children. JAMA Pediatr. 170, 117-124. doi:10.1001/jamapediatrics.2015.3356

Boulle, F., Pawluski, J.L., Homberg, J.R., Machiels, B., Kroeze, Y., Kumar, N., Steinbusch, H.W.M., Kenis, G., van den Hove, D.L.A., 2016a. Developmental fluoxetine exposure increases behavioral despair and alters epigenetic regulation of the hippocampal BDNF gene in adult female offspring. Horm. Behav. 80, 47-57. doi:10.1016/j.yhbeh.2016.01.017

Boulle, F., Pawluski, J.L., Homberg, J.R., Machiels, B., Kroeze, Y., Kumar, N., Steinbusch, H.W.M., Kenis, G., Van den Hove, D.L.A., 2016b. Prenatal stress and early-life exposure to fluoxetine have enduring effects on anxiety and hippocampal BDNF gene expression in adult male offspring. Dev. Psychobiol. 58, 427-438. doi:10.1002/dev.21385

Brambilla, P., Perez, J., Barale, F., Schettini, G., Soares, J.C., 2003. GABAergic dysfunction in mood disorders. Mol. Psychiatry 8, 721-737, 715. doi:10.1038/sj.mp.4001362

Brown, H.K., Ray, J.G., Wilton, A.S., Lunsky, Y., Gomes, T., Vigod, S.N., 2017. Association Between Serotonergic Antidepressant Use During Pregnancy and Autism Spectrum Disorder in Children. JAMA 317, 1544-1552. doi:10.1001/jama.2017.3415

Cabrera-Vera, T.M., Battaglia, G., 1998. Prenatal exposure to fluoxetine (Prozac) produces sitespecific and age-dependent alterations in brain serotonin transporters in rat progeny: evidence from autoradiographic studies. J. Pharmacol. Exp. Ther. 286, 1474-1481.

Casper, R.C., Fleisher, B.E., Lee-Ancajas, J.C., Gilles, A., Gaylor, E., DeBattista, A., Hoyme, H.E., 2003. Follow-up of children of depressed mothers exposed or not exposed to antidepressant drugs during pregnancy. J. Pediatr. 142, 402-408. doi:10.1067/mpd.2003.139

Casper, R.C., Gilles, A.A., Fleisher, B.E., Baran, J., Enns, G., Lazzeroni, L.C., 2011. Length of prenatal exposure to selective serotonin reuptake inhibitor (SSRI) antidepressants: effects on neonatal adaptation and psychomotor development. Psychopharmacology (Berl.) 217, 211219. doi:10.1007/s00213-011-2270-z

Caspi, A., Sugden, K., Moffitt, T.E., Taylor, A., Craig, I.W., Harrington, H., McClay, J., Mill, J., Martin, J., Braithwaite, A., Poulton, R., 2003. Influence of Life Stress on Depression: Moderation by a Polymorphism in the 5-HTT Gene. Science 301, 386-389. doi:10.1126/science.1083968

Castrén, E., Rantamäki, T., 2010. The role of BDNF and its receptors in depression and antidepressant drug action: Reactivation of developmental plasticity. Dev. Neurobiol. 70, 289-297. doi:10.1002/dneu.20758

Chen, X., Petit, E.I., Dobrenis, K., Sze, J.Y., 2016. Spatiotemporal SERT expression in cortical map development. Neurochem. Int., Special Issue: Brain Transporters: From Genes and Genetic Disorders to Function and Drug Discovery 98, 129-137. doi:10.1016/j.neuint.2016.05.010

Chen, X., Ye, R., Gargus, J.J., Blakely, R.D., Dobrenis, K., Sze, J.Y., 2015. Disruption of Transient Serotonin Accumulation by Non-Serotonin-Producing Neurons Impairs Cortical Map Development. Cell Rep. 10, 346-358. doi:10.1016/j.celrep.2014.12.033

Clancy, B., Finlay, B.L., Darlington, R.B., Anand, K.J.S., 2007. Extrapolating brain development from experimental species to humans. NeuroToxicology 28, 931-937. doi:10.1016/j.neuro.2007.01.014

Clements, C.C., Castro, V.M., Blumenthal, S.R., Rosenfield, H.R., Murphy, S.N., Fava, M., Erb, J.L., Churchill, S.E., Kaimal, A.J., Doyle, A.E., Robinson, E.B., Smoller, J.W., Kohane, I.S., Perlis, 
R.H., 2015. Prenatal antidepressant exposure is associated with risk for attention deficithyperactivity disorder but not autism spectrum disorder in a large health system. Mol. Psychiatry 20, 727-734. doi:10.1038/mp.2014.90

Cnattingius, S., 2004. The epidemiology of smoking during pregnancy: Smoking prevalence, maternal characteristics, and pregnancy outcomes. Nicotine Tob. Res. 6, S125-S140. doi:10.1080/14622200410001669187

Coghlan, S., Horder, J., Inkster, B., Mendez, M.A., Murphy, D.G., Nutt, D.J., 2012. GABA system dysfunction in autism and related disorders: From synapse to symptoms. Neurosci. Biobehav. Rev. 36, 2044-2055. doi:10.1016/j.neubiorev.2012.07.005

Constantino, J.N., Davis, S.A., Todd, R.D., Schindler, M.K., Gross, M.M., Brophy, S.L., Metzger, L.M., Shoushtari, C.S., Splinter, R., Reich, W., 2003. Validation of a Brief Quantitative Measure of Autistic Traits: Comparison of the Social Responsiveness Scale with the Autism Diagnostic Interview-Revised. J. Autism Dev. Disord. 33, 427-433. doi:10.1023/A:1025014929212

Cooper, W.O., Willy, M.E., Pont, S.J., Ray, W.A., 2007. Increasing use of antidepressants in pregnancy. Am. J. Obstet. Gynecol. 196, 544.e1-544.e5. doi:10.1016/j.ajog.2007.01.033

Croen, L.A., Grether, J.K., Yoshida, C.K., Odouli, R., Hendrick, V., 2011. Antidepressant use during pregnancy and childhood autism spectrum disorders. Arch. Gen. Psychiatry 68, 1104-1112. doi:10.1001/archgenpsychiatry.2011.73

Davalos, D.B., Yadon, C.A., Tregellas, H.C., 2012. Untreated prenatal maternal depression and the potential risks to offspring: a review. Arch. Womens Ment. Health 15, 1-14. doi:10.1007/s00737-011-0251-1

Davidson, S., Prokonov, D., Taler, M., Maayan, R., Harell, D., Gil-Ad, I., Weizman, A., 2009. Effect of exposure to selective serotonin reuptake inhibitors in utero on fetal growth: potential role for the IGF-I and HPA axes. Pediatr. Res. 65, 236-241. doi:10.1203/PDR.0b013e318193594a

Davis, R.L., Rubanowice, D., McPhillips, H., Raebel, M.A., Andrade, S.E., Smith, D., Yood, M.U., Platt, R., HMO Research Network Center for Education, Research in Therapeutics, 2007. Risks of congenital malformations and perinatal events among infants exposed to antidepressant medications during pregnancy. Pharmacoepidemiol. Drug Saf. 16, 1086-1094. doi:10.1002/pds.1462

Deave, T., Heron, J., Evans, J., Emond, A., 2008. The impact of maternal depression in pregnancy on early child development. BJOG Int. J. Obstet. Gynaecol. 115, 1043-1051. doi:10.1111/j.14710528.2008.01752.x

Dölen, G., Osterweil, E., Rao, B.S.S., Smith, G.B., Auerbach, B.D., Chattarji, S., Bear, M.F., 2007. Correction of Fragile X Syndrome in Mice. Neuron 56, 955-962. doi:10.1016/j.neuron.2007.12.001

Duman, R.S., Malberg, J., Nakagawa, S., D'Sa, C., 2000. Neuronal plasticity and survival in mood disorders. Biol. Psychiatry 48, 732-739. doi:10.1016/S0006-3223(00)00935-5

Dwivedi, Y., Rizavi, H.S., Conley, R.R., Roberts, R.C., Tamminga, C.A., Pandey, G.N., 2003. Altered Gene Expression of Brain-Derived Neurotrophic Factor and Receptor Tyrosine Kinase B in Postmortem Brain of Suicide Subjects. Arch. Gen. Psychiatry 60, 804. doi:10.1001/archpsyc.60.8.804

Edgar, J.M., Price, D.J., 2001. Radial migration in the cerebral cortex is enhanced by signals from thalamus. Eur. J. Neurosci. 13, 1745-1754.

Ewing, G., Tatarchuk, Y., Appleby, D., Schwartz, N., Kim, D., 2015. Placental transfer of antidepressant medications: implications for postnatal adaptation syndrome. Clin. Pharmacokinet. 54, 359-370. doi:10.1007/s40262-014-0233-3

Eyler, F.D., Behnke, M., Conlon, M., Woods, N.S., Wobie, K., 1998. Birth Outcome From a Prospective, Matched Study of Prenatal Crack/Cocaine Use: I. Interactive and Dose Effects on Health and Growth. Pediatrics 101, 229-236. doi:10.1542/peds.101.2.229 
Figueroa, R., 2010. Use of antidepressants during pregnancy and risk of attentiondeficit/hyperactivity disorder in the offspring. J. Dev. Behav. Pediatr. JDBP 31, 641-648. doi:10.1097/DBP.0b013e3181e5ac93

Francis-Oliveira, J., Ponte, B., Barbosa, A.P.M., Veríssimo, L.F., Gomes, M.V., Pelosi, G.G., de Britto, L.R.G., Moreira, E.G., 2013. Fluoxetine exposure during pregnancy and lactation: Effects on acute stress response and behavior in the novelty-suppressed feeding are age and genderdependent in rats. Behav. Brain Res. 252, 195-203. doi:10.1016/j.bbr.2013.05.064

Galbally, M., Lewis, A.J., Buist, A., 2011. Developmental outcomes of children exposed to antidepressants in pregnancy. Aust. N. Z. J. Psychiatry 45, 393-399. doi:10.3109/00048674.2010.549995

Galbally, M., Lewis, A.J., Lum, J., Buist, A., 2009. Serotonin discontinuation syndrome following in utero exposure to antidepressant medication: prospective controlled study. Aust. N. Z. J. Psychiatry 43, 846-854. doi:10.1080/00048670903107583

Gaspar, P., Cases, O., Maroteaux, L., 2003. The developmental role of serotonin: news from mouse molecular genetics. Nat. Rev. Neurosci. 4, 1002-1012. doi:10.1038/nrn1256

Gentile, S., 2015. Untreated depression during pregnancy: Short- and long-term effects in offspring. A systematic review. Neuroscience. doi:10.1016/j.neuroscience.2015.09.001

Gidaya, N.B., Lee, B.K., Burstyn, I., Yudell, M., Mortensen, E.L., Newschaffer, C.J., 2014. In Utero Exposure to Selective Serotonin Reuptake Inhibitors and Risk for Autism Spectrum Disorder. J. Autism Dev. Disord. 44, 2558-2567. doi:10.1007/s10803-014-2128-4

Glover, M.E., Clinton, S.M., 2016. Of rodents and humans: A comparative review of the neurobehavioral effects of early life SSRI exposure in preclinical and clinical research. Int. J. Dev. Neurosci. Off. J. Int. Soc. Dev. Neurosci. 51, 50-72. doi:10.1016/j.ijdevneu.2016.04.008

Glover, M.E., Pugh, P.C., Jackson, N.L., Cohen, J.L., Fant, A.D., Akil, H., Clinton, S.M., 2015. Early-life exposure to the SSRI paroxetine exacerbates depression-like behavior in anxiety/depressionprone rats. Neuroscience 284, 775-797. doi:10.1016/j.neuroscience.2014.10.044

Glover, V., 2014. Maternal depression, anxiety and stress during pregnancy and child outcome; what needs to be done. Best Pract. Res. Clin. Obstet. Gynaecol., Perinatal Mental Health: Guidance for the Obstetrician-Gynaecologist 28, 25-35. doi:10.1016/j.bpobgyn.2013.08.017

Grabe, H.J., Ahrens, N., Rose, H.J., Kessler, C., Freyberger, H.J., 2001. Neurotrophic factor S100 beta in major depression. Neuropsychobiology 44, 88-90. doi:54922

Hammen, C., Brennan, P.A., 2003. Severity, chronicity, and timing of maternal depression and risk for adolescent offspring diagnoses in a community sample. Arch. Gen. Psychiatry 60, 253-258.

Hanley, G.E., Brain, U., Oberlander, T.F., 2015. Prenatal exposure to serotonin reuptake inhibitor antidepressants and childhood behavior. Pediatr. Res. 78, 174-180. doi:10.1038/pr.2015.77

Hanley, G.E., Brain, U., Oberlander, T.F., 2013. Infant developmental outcomes following prenatal exposure to antidepressants, and maternal depressed mood and positive affect. Early Hum. Dev. 89, 519-524. doi:10.1016/j.earlhumdev.2012.12.012

Hansson, S.R., Mezey, É., Hoffman, B.J., 1998. Serotonin transporter messenger RNA in the developing rat brain: early expression in serotonergic neurons and transient expression in non-serotonergic neurons. Neuroscience 83, 1185-1201. doi:10.1016/S03064522(97)00444-2

Harrington, R.A., Lee, L.-C., Crum, R.M., Zimmerman, A.W., Hertz-Picciotto, I., 2014. Prenatal SSRI Use and Offspring With Autism Spectrum Disorder or Developmental Delay. Pediatrics peds.2013-3406. doi:10.1542/peds.2013-3406

Hashemi, E., Ariza, J., Rogers, H., Noctor, S.C., Martínez-Cerdeño, V., 2016. The Number of Parvalbumin-Expressing Interneurons Is Decreased in the Medial Prefrontal Cortex in Autism. Cereb. Cortex N. Y. N 1991. doi:10.1093/cercor/bhw021

Hashimoto, K., 2010. Brain-derived neurotrophic factor as a biomarker for mood disorders: An historical overview and future directions. Psychiatry Clin. Neurosci. 64, 341-357. doi:10.1111/j.1440-1819.2010.02113.x 
Heikkinen, T., Ekblad, U., Laine, K., 2002. Transplacental transfer of citalopram, fluoxetine and their primary demethylated metabolites in isolated perfused human placenta. BJOG Int. J. Obstet. Gynaecol. 109, 1003-1008. doi:10.1111/j.1471-0528.2002.01467.x

Heisler, L.K., Pronchuk, N., Nonogaki, K., Zhou, L., Raber, J., Tung, L., Yeo, G.S.H., O'Rahilly, S., Colmers, W.F., Elmquist, J.K., Tecott, L.H., 2007a. Serotonin Activates the HypothalamicPituitary-Adrenal Axis via Serotonin 2C Receptor Stimulation. J. Neurosci. 27, 6956-6964. doi:10.1523/JNEUROSCI.2584-06.2007

Heisler, L.K., Zhou, L., Bajwa, P., Hsu, J., Tecott, L.H., 2007b. Serotonin 5-HT(2C) receptors regulate anxiety-like behavior. Genes Brain Behav. 6, 491-496. doi:10.1111/j.1601183X.2007.00316.X

Hendrick, V., Smith, L.M., Suri, R., Hwang, S., Haynes, D., Altshuler, L., 2003. Birth outcomes after prenatal exposure to antidepressant medication. Am. J. Obstet. Gynecol. 188, 812-815. doi:10.1067/mob.2003.172

Hendrick, V., Stowe, Z.N., Altshuler, L.L., Mintz, J., Hwang, S., Hostetter, A., Suri, R., Leight, K., Fukuchi, A., 2001. Fluoxetine and norfluoxetine concentrations in nursing infants and breast milk. Biol. Psychiatry 50, 775-782. doi:10.1016/S0006-3223(01)01197-0

Hermansen, T.K., Røysamb, E., Augusti, E.-M., Melinder, A., 2016. Behavior and inhibitory control in children with prenatal exposure to antidepressants and medically untreated depression. Psychopharmacology (Berl.) 233, 1523-1535. doi:10.1007/s00213-016-4248-3

Hiemke, C., Härtter, S., 2000. Pharmacokinetics of selective serotonin reuptake inhibitors. Pharmacol. Ther. 85, 11-28. doi:10.1016/S0163-7258(99)00048-0

Hillion, J., Catelon, J., Raid, M., Hamon, M., De Vitry, F., 1994. Neuronal localization of 5-HT1A receptor mRNA and protein in rat embryonic brain stem cultures. Brain Res. Dev. Brain Res. 79, 195-202.

Hines, R.N., McCarver, D.G., 2002. The ontogeny of human drug-metabolizing enzymes: phase I oxidative enzymes. J. Pharmacol. Exp. Ther. 300, 355-360.

Holden, S.E., Jenkins-Jones, S., Poole, C.D., Morgan, C.L., Coghill, D., Currie, C.J., 2013. The prevalence and incidence, resource use and financial costs of treating people with attention deficit/hyperactivity disorder (ADHD) in the United Kingdom (1998 to 2010). Child Adolesc. Psychiatry Ment. Health 7, 34. doi:10.1186/1753-2000-7-34

Homberg, J.R., Molteni, R., Calabrese, F., Riva, M.A., 2014. The serotonin-BDNF duo: Developmental implications for the vulnerability to psychopathology. Neurosci. Biobehav. Rev. 43, 35-47. doi:10.1016/j.neubiorev.2014.03.012

Homberg, J.R., Schubert, D., Gaspar, P., 2010. New perspectives on the neurodevelopmental effects of SSRIs. Trends Pharmacol. Sci. 31, 60-65. doi:10.1016/j.tips.2009.11.003

Hornung, J.-P., 2003. The human raphe nuclei and the serotonergic system. J. Chem. Neuroanat., Special Issue on the Human Brain - The Structural Basis for understanding Human Brain function and dysfunction 26, 331-343. doi:10.1016/j.jchemneu.2003.10.002

Hranilovic, D., Bujas-Petkovic, Z., Vragovic, R., Vuk, T., Hock, K., Jernej, B., 2007. Hyperserotonemia in adults with autistic disorder. J. Autism Dev. Disord. 37, 1934-1940. doi:10.1007/s10803-0060324-6

Huang, H., Coleman, S., Bridge, J.A., Yonkers, K., Katon, W., 2014. A meta-analysis of the relationship between antidepressant use in pregnancy and the risk of preterm birth and low birth weight. Gen. Hosp. Psychiatry 36, 13-18. doi:10.1016/j.genhosppsych.2013.08.002

Huybrechts, K.F., Palmsten, K., Mogun, H., Kowal, M., Avorn, J., Setoguchi-Iwata, S., Hernández-Díaz, S., 2013. National trends in antidepressant medication treatment among publicly insured pregnant women. Gen. Hosp. Psychiatry 35, 265-271.

doi:10.1016/j.genhosppsych.2012.12.010

Ikeda, M., Iwata, N., Kitajima, T., Suzuki, T., Yamanouchi, Y., Kinoshita, Y., Ozaki, N., 2005. Positive Association of the Serotonin 5-HT7 Receptor Gene with Schizophrenia in a Japanese Population. Neuropsychopharmacology 31, 866-871. doi:10.1038/sj.npp.1300901 
Jensen, C.M., Steinhausen, H., Lauritsen, M.B., 2014. Time Trends Over 16 Years in Incidence-Rates of Autism Spectrum Disorders Across the Lifespan Based on Nationwide Danish Register Data. J. Autism Dev. Disord. N. Y. 44, 1808-18. doi:http://dx.doi.org.ezproxy.uow.edu.au/10.1007/s10803-014-2053-6

Jensen, H.M., Grøn, R., Lidegaard, Ø., Pedersen, L.H., Andersen, P.K., Kessing, L.V., 2013. Maternal depression, antidepressant use in pregnancy and Apgar scores in infants. Br. J. Psychiatry J. Ment. Sci. 202, 347-351. doi:10.1192/bjp.bp.112.115931

Källén, B., 2004. Neonate characteristics after maternal use of antidepressants in late pregnancy. Arch. Pediatr. Adolesc. Med. 158, 312-316. doi:10.1001/archpedi.158.4.312

Källén, B.A.J., Otterblad Olausson, P., 2007. Maternal use of selective serotonin re-uptake inhibitors in early pregnancy and infant congenital malformations. Birt. Defects Res. A. Clin. Mol. Teratol. 79, 301-308. doi:10.1002/bdra.20327

Karpova, N.N., Lindholm, J., Pruunsild, P., Timmusk, T., Castrén, E., 2009. Long-lasting behavioural and molecular alterations induced by early postnatal fluoxetine exposure are restored by chronic fluoxetine treatment in adult mice. Eur. Neuropsychopharmacol. 19, 97-108. doi:10.1016/j.euroneuro.2008.09.002

Kessler, R., 2003. Epidemiology of women and depression. J. Affect. Disord. 74, 5-13. doi:10.1016/S0165-0327(02)00426-3

Kim, J., Riggs, K.W., Misri, S., Kent, N., Oberlander, T.F., Grunau, R.E., Fitzgerald, C., Rurak, D.W., 2006. Stereoselective disposition of fluoxetine and norfluoxetine during pregnancy and breast-feeding. Br. J. Clin. Pharmacol. 61, 155-163. doi:10.1111/j.1365-2125.2005.02538.x

Kim, J.S., Schmid-Burgk, W., Claus, D., Kornhuber, H.H., 1982. Increased serum glutamate in depressed patients. Arch. Für Psychiatr. Nervenkrankh. 232, 299-304. doi:10.1007/BF00345492

Kiryanova, V., Meunier, S.J., Vecchiarelli, H.A., Hill, M.N., Dyck, R.H., 2016. Effects of maternal stress and perinatal fluoxetine exposure on behavioral outcomes of adult male offspring. Neuroscience 320, 281-296. doi:10.1016/j.neuroscience.2016.01.064

Kleindienst, A., Hesse, F., Bullock, M.R., Buchfelder, M., 2007. The neurotrophic protein S100B: value as a marker of brain damage and possible therapeutic implications. Prog. Brain Res. 161, 317-325. doi:10.1016/S0079-6123(06)61022-4

Knable, M.B., Barci, B.M., Webster, M.J., Meador-Woodruff, J., Torrey, E.F., 2004. Molecular abnormalities of the hippocampus in severe psychiatric illness: postmortem findings from the Stanley Neuropathology Consortium. Mol. Psychiatry 9, 609-620. doi:10.1038/sj.mp.4001471

Kornum, J.B., Nielsen, R.B., Pedersen, L., Mortensen, P.B., Nørgaard, M., 2010. Use of selective serotonin-reuptake inhibitors during early pregnancy and risk of congenital malformations: updated analysis. Clin. Epidemiol. 2, 29.

Küçükibrahimoğlu, E., Saygın, M.Z., Çalışkan, M., Kaplan, O.K., Ünsal, C., Gören, M.Z., 2009. The change in plasma GABA, glutamine and glutamate levels in fluoxetine- or S-citalopramtreated female patients with major depression. Eur. J. Clin. Pharmacol. 65, 571-577. doi:10.1007/s00228-009-0650-7

Laine, K., Heikkinen, T., Ekblad, U., Kero, P., 2003. Effects of exposure to selective serotonin reuptake inhibitors during pregnancy on serotonergic symptoms in newborns and cord blood monoamine and prolactin concentrations. Arch. Gen. Psychiatry 60, 720-726. doi:10.1001/archpsyc.60.7.720

Lambe, E.K., Fillman, S.G., Webster, M.J., Weickert, C.S., 2011. Serotonin Receptor Expression in Human Prefrontal Cortex: Balancing Excitation and Inhibition across Postnatal Development. PLOS ONE 6, e22799. doi:10.1371/journal.pone.0022799

Lavdas, A.A., Blue, M.E., Lincoln, J., Parnavelas, J.G., 1997. Serotonin promotes the differentiation of glutamate neurons in organotypic slice cultures of the developing cerebral cortex. J. Neurosci. Off. J. Soc. Neurosci. 17, 7872-7880. 
Lee, L.-J., 2009. Neonatal fluoxetine exposure affects the neuronal structure in the somatosensory cortex and somatosensory-related behaviors in adolescent rats. Neurotox. Res. 15, 212-223. doi:10.1007/s12640-009-9022-4

Lee, L.-J., Lee, L.J.-H., 2012. Neonatal fluoxetine exposure alters motor performances of adolescent rats. Dev. Neurobiol. 72, 1122-1132. doi:10.1002/dneu.20942

Lemos, J.C., Zhang, G., Walsh, T., Kirby, L.G., Akanwa, A., Brooks-Kayal, A., Beck, S.G., 2011. StressHyperresponsive WKY Rats Demonstrate Depressed Dorsal Raphe Neuronal Excitability and Dysregulated CRF-Mediated Responses. Neuropsychopharmacology 36, 721-734. doi:10.1038/npp.2010.200

Levinson-Castiel, R., Merlob, P., Linder, N., Sirota, L., Klinger, G., 2006. Neonatal abstinence syndrome after in utero exposure to selective serotonin reuptake inhibitors in term infants. Arch. Pediatr. Adolesc. Med. 160, 173-176. doi:10.1001/archpedi.160.2.173

Li, Q., Wichems, C., Heils, A., Lesch, K.P., Murphy, D.L., 2000. Reduction in the density and expression, but not G-protein coupling, of serotonin receptors (5-HT1A) in 5-HT transporter knock-out mice: gender and brain region differences. J. Neurosci. Off. J. Soc. Neurosci. 20, 7888-7895.

Li, Q., Wichems, C.H., Ma, L., Van de Kar, L.D., Garcia, F., Murphy, D.L., 2003. Brain region-specific alterations of 5-HT2A and 5-HT2C receptors in serotonin transporter knockout mice. J. Neurochem. 84, 1256-1265.

Lidow, M.S., Rakic, P., 1995. Neurotransmitter receptors in the proliferative zones of the developing primate occipital lobe. J. Comp. Neurol. 360, 393-402. doi:10.1002/cne.903600303

Lin, L.-C., Sibille, E., 2013. Reduced brain somatostatin in mood disorders: a common pathophysiological substrate and drug target? Front. Pharmacol. 4. doi:10.3389/fphar.2013.00110

Lisboa, S.F.S., Oliveira, P.E., Costa, L.C., Venâncio, E.J., Moreira, E.G., 2007. Behavioral Evaluation of Male and Female Mice Pups Exposed to Fluoxetine during Pregnancy and Lactation. Pharmacology 80, 49-56. doi:10.1159/000103097

Marroun, H.E., White, T.J.H., Knaap, N.J.F. van der, Homberg, J.R., Fernández, G., Schoemaker, N.K., Jaddoe, V.W.V., Hofman, A., Verhulst, F.C., Hudziak, J.J., Stricker, B.H.C., Tiemeier, H., 2014. Prenatal exposure to selective serotonin reuptake inhibitors and social responsiveness symptoms of autism: population-based study of young children. Br. J. Psychiatry 205, 95102. doi:10.1192/bjp.bp.113.127746

Martinowich, K., Lu, B., 2007. Interaction between BDNF and Serotonin: Role in Mood Disorders. Neuropsychopharmacology 33, 73-83. doi:10.1038/sj.npp.1301571

Maschi, S., Clavenna, A., Campi, R., Schiavetti, B., Bernat, M., Bonati, M., 2008. Neonatal outcome following pregnancy exposure to antidepressants: a prospective controlled cohort study. BJOG Int. J. Obstet. Gynaecol. 115, 283-289. doi:10.1111/j.1471-0528.2007.01518.x

Mazefsky, C.A., Anderson, R., Conner, C.M., Minshew, N., 2011. Child Behavior Checklist Scores for School-Aged Children with Autism: Preliminary Evidence of Patterns Suggesting the Need for Referral. J. Psychopathol. Behav. Assess. 33, 31. doi:10.1007/s10862-010-9198-1

McAllister, B.B., Kiryanova, V., Dyck, R.H., 2012. Behavioural outcomes of perinatal maternal fluoxetine treatment. Neuroscience 226, 356-366. doi:10.1016/j.neuroscience.2012.09.024

Misri, S., Reebye, P., Kendrick, K., Carter, D., Ryan, D., Grunau, R.E., Oberlander, T.F., 2006. Internalizing behaviors in 4-year-old children exposed in utero to psychotropic medications. Am. J. Psychiatry 163, 1026-1032. doi:10.1176/ajp.2006.163.6.1026

Mitani, H., Shirayama, Y., Yamada, T., Maeda, K., Ashby Jr., C.R., Kawahara, R., 2006. Correlation between plasma levels of glutamate, alanine and serine with severity of depression. Prog. Neuropsychopharmacol. Biol. Psychiatry 30, 1155-1158. doi:10.1016/j.pnpbp.2006.03.036

Mitchell, A.A., Gilboa, S.M., Werler, M.M., Kelley, K.E., Louik, C., Hernández-Díaz, S., National Birth Defects Prevention Study, 2011. Medication use during pregnancy, with particular focus on 
prescription drugs: 1976-2008. Am. J. Obstet. Gynecol. 205, 51.e1-8. doi:10.1016/j.ajog.2011.02.029

Moore, M., Yuen, H.M., Dunn, N., Mullee, M.A., Maskell, J., Kendrick, T., 2009. Explaining the rise in antidepressant prescribing: a descriptive study using the general practice research database. BMJ 339, b3999-b3999. doi:10.1136/bmj.b3999

Morrison, J.L., Riggs, K.W., Chien, C., Gruber, N., McMillen, I.C., Rurak, D.W., 2004. Chronic maternal fluoxetine infusion in pregnant sheep: effects on the maternal and fetal hypothalamicpituitary-adrenal axes. Pediatr. Res. 56, 40-46. doi:10.1203/01.PDR.0000128981.38670.28

Mulder, E.J., Anderson, G.M., Kema, I.P., de Bildt, A., van Lang, N.D., den Boer, J.A., Minderaa, R.B., 2004. Platelet Serotonin Levels in Pervasive Developmental Disorders and Mental Retardation: Diagnostic Group Differences, Within-Group Distribution, and Behavioral Correlates. J. Am. Acad. Child Adolesc. Psychiatry 43, 491-499. doi:10.1097/00004583200404000-00016

Murray, L., Arteche, A., Fearon, P., Halligan, S., Goodyer, I., Cooper, P., 2011. Maternal Postnatal Depression and the Development of Depression in Offspring Up to 16 Years of Age. J. Am. Acad. Child Adolesc. Psychiatry 50, 460-470. doi:10.1016/j.jaac.2011.02.001

Murthy, S., Niquille, M., Hurni, N., Limoni, G., Frazer, S., Chameau, P., van Hooft, J.A., Vitalis, T., Dayer, A., 2014. Serotonin receptor $3 A$ controls interneuron migration into the neocortex. Nat. Commun. 5, 5524. doi:10.1038/ncomms6524

Narboux-Nême, N., Pavone, L.M., Avallone, L., Zhuang, X., Gaspar, P., 2008. Serotonin transporter transgenic (SERTcre) mouse line reveals developmental targets of serotonin specific reuptake inhibitors (SSRIs). Neuropharmacology 55, 994-1005. doi:10.1016/j.neuropharm.2008.08.020

Newschaffer, C.J., Croen, L.A., Daniels, J., Giarelli, E., Grether, J.K., Levy, S.E., Mandell, D.S., Miller, L.A., Pinto-Martin, J., Reaven, J., Reynolds, A.M., Rice, C.E., Schendel, D., Windham, G.C., 2007. The Epidemiology of Autism Spectrum Disorders. Annu. Rev. Public Health 28, 235258. doi:10.1146/annurev.publhealth.28.021406.144007

Nishimura, H., Tsuda, A., Oguchi, M., Ida, Y., Tanaka, M., 1988. Is immobility of rats in the forced swim test "behavioral despair"? Physiol. Behav. 42, 93-95.

Noorlander, C.W., Ververs, F.F.T., Nikkels, P.G.J., Echteld, C.J.A. van, Visser, G.H.A., Smidt, M.P., 2008. Modulation of Serotonin Transporter Function during Fetal Development Causes Dilated Heart Cardiomyopathy and Lifelong Behavioral Abnormalities. PLOS ONE 3, e2782. doi:10.1371/journal.pone.0002782

Nordeng, H., Lindemann, R., Perminov, K., Reikvam, A., 2001. Neonatal withdrawal syndrome after in utero exposure to selective serotonin reuptake inhibitors. Acta Pædiatrica 90, 288-291. doi:10.1111/j.1651-2227.2001.tb00306.x

Nøvik, T.S., 1999. Validity of the Child Behaviour Checklist in a Norwegian sample. Eur. Child Adolesc. Psychiatry 8, 247-254. doi:10.1007/s007870050098

Nulman, I., Koren, G., Rovet, J., Barrera, M., Pulver, A., Streiner, D., Feldman, B., 2012. Neurodevelopment of children following prenatal exposure to venlafaxine, selective serotonin reuptake inhibitors, or untreated maternal depression. Am. J. Psychiatry 169, 1165-1174. doi:10.1176/appi.ajp.2012.11111721

Nulman, I., Rovet, J., Stewart, D.E., Wolpin, J., Pace-Asciak, P., Shuhaiber, S., Koren, G., 2002. Child development following exposure to tricyclic antidepressants or fluoxetine throughout fetal life: a prospective, controlled study. Am. J. Psychiatry 159, 1889-1895. doi:10.1176/appi.ajp.159.11.1889

Oades, R.D., Slusarek, M., Veiling, S., Bondy, B., 2002. Serotonin Platelet-Transporter Measures in Childhood Attention-Deficit/Hyperactivity Disorder (ADHD): Clinical versus Experimental Measures of Impulsivity. World J. Biol. Psychiatry 3, 96-100.

doi:10.3109/15622970209150607 
Oates, M., 2003. Perinatal psychiatric disorders: a leading cause of maternal morbidity and mortality. Br. Med. Bull. 67, 219-229. doi:10.1093/bmb/ldg011

Oberlander, T.F., Gingrich, J.A., Ansorge, M.S., 2009. Sustained neurobehavioral effects of exposure to SSRI antidepressants during development: molecular to clinical evidence. Clin. Pharmacol. Ther. 86, 672-677. doi:10.1038/clpt.2009.201

Oberlander, T.F., Grunau, R., Mayes, L., Riggs, W., Rurak, D., Papsdorf, M., Misri, S., Weinberg, J., 2008. Hypothalamic-pituitary-adrenal (HPA) axis function in 3-month old infants with prenatal selective serotonin reuptake inhibitor (SSRI) antidepressant exposure. Early Hum. Dev. 84, 689-697. doi:10.1016/j.earlhumdev.2008.06.008

Oberlander, T.F., Papsdorf, M., Brain, U.M., Misri, S., Ross, C., Grunau, R.E., 2010. Prenatal Effects of Selective Serotonin Reuptake Inhibitor Antidepressants, Serotonin Transporter Promoter Genotype (SLC6A4), and Maternal Mood on Child Behavior at 3 Years of Age. Arch. Pediatr. Adolesc. Med. 164, 444-451. doi:10.1001/archpediatrics.2010.51

Oberlander, T.F., Warburton, W., Misri, S., Aghajanian, J., Hertzman, C., 2006. Neonatal outcomes after prenatal exposure to selective serotonin reuptake inhibitor antidepressants and maternal depression using population-based linked health data. Arch. Gen. Psychiatry 63, 898-906. doi:10.1001/archpsyc.63.8.898

O'Connor, T.G., Heron, J., Golding, J., Beveridge, M., Glover, V., 2002. Maternal antenatal anxiety and children's behavioural/emotional problems at 4 years. Report from the Avon Longitudinal Study of Parents and Children. Br. J. Psychiatry J. Ment. Sci. 180, 502-508.

O'Connor, T.G., Heron, J., Golding, J., Glover, V., ALSPAC Study Team, 2003. Maternal antenatal anxiety and behavioural/emotional problems in children: a test of a programming hypothesis. J. Child Psychol. Psychiatry 44, 1025-1036.

Olfson, M., Marcus, S.C., 2009. National Patterns in Antidepressant Medication Treatment. Arch. Gen. Psychiatry 66, 848-856. doi:10.1001/archgenpsychiatry.2009.81

Olivier, J.D.A., Vallès, A., Heesch, F. van, Afrasiab-Middelman, A., Roelofs, J.J.P.M., Jonkers, M., Peeters, E.J., Korte-Bouws, G.A.H., Dederen, J.P., Kiliaan, A.J., Martens, G.J., Schubert, D., Homberg, J.R., 2011. Fluoxetine administration to pregnant rats increases anxiety-related behavior in the offspring. Psychopharmacology (Berl.) 217, 419. doi:10.1007/s00213-0112299-z

Ornoy, A., Ergaz, Z., 2010. Alcohol Abuse in Pregnant Women: Effects on the Fetus and Newborn, Mode of Action and Maternal Treatment. Int. J. Environ. Res. Public. Health 7, 364. doi:10.3390/ijerph7020364

Paré, W.P., 1994. Open field, learned helplessness, conditioned defensive burying, and forced-swim tests in WKY rats. Physiol. Behav. 55, 433-439. doi:10.1016/0031-9384(94)90097-3

Pare, W.P., Tejani-Butt, S.M., 1996. Effect of stress on the behavior and 5-HT system in SpragueDawley and Wistar Kyoto rat strains. Integr. Physiol. Behav. Sci. 31, 112.

Patil, A.S., Kuller, J.A., Rhee, E.H.J., 2011. Antidepressants in pregnancy: a review of commonly prescribed medications. Obstet. Gynecol. Surv. 66, 777-787. doi:10.1097/OGX.0b013e31823e0cbf

Paus, T., Keshavan, M., Giedd, J.N., 2008. Why do many psychiatric disorders emerge during adolescence? Nat. Rev. Neurosci. 9, 947-957. doi:10.1038/nrn2513

Pawluski, J.L., Brain, U.M., Underhill, C.M., Hammond, G.L., Oberlander, T.F., 2012. Prenatal SSRI exposure alters neonatal corticosteroid binding globulin, infant cortisol levels, and emerging HPA function. Psychoneuroendocrinology 37, 1019-1028. doi:10.1016/j.psyneuen.2011.11.011

Pawluski, J.L., Galea, L.A.M., Brain, U., Papsdorf, M., Oberlander, T.F., 2009. Neonatal S100B protein levels after prenatal exposure to selective serotonin reuptake inhibitors. Pediatrics 124 , e662-670. doi:10.1542/peds.2009-0442 
Pedersen, L.H., Henriksen, T.B., Vestergaard, M., Olsen, J., Bech, B.H., 2009. Selective serotonin reuptake inhibitors in pregnancy and congenital malformations: population based cohort study. BMJ 339, b3569. doi:10.1136/bmj.b3569

Persico, A.M., Mengual, E., Moessner, R., Hall, S.F., Revay, R.S., Sora, I., Arellano, J., DeFelipe, J., Giménez-Amaya, J.M., Conciatori, M., Marino, R., Baldi, A., Cabib, S., Pascucci, T., Uhl, G.R., Murphy, D.L., Lesch, K.P., Keller, F., 2001. Barrel Pattern Formation Requires Serotonin Uptake by Thalamocortical Afferents, and Not Vesicular Monoamine Release. J. Neurosci. 21, 6862-6873.

Quan-Bui, K.H.L., Plaisant, O., Leboyer, M., Gay, C., Kamal, L., Devynck, M.-A., Meyer, P., 1984. Reduced platelet serotonin in depression. Psychiatry Res. 13, 129-139. doi:10.1016/01651781(84)90056-8

Rai, D., Lee, B.K., Dalman, C., Golding, J., Lewis, G., Magnusson, C., 2013. Parental depression, maternal antidepressant use during pregnancy, and risk of autism spectrum disorders: population based case-control study. BMJ 346, f2059. doi:10.1136/bmj.f2059

Rayen, I., van den Hove, D.L., Prickaerts, J., Steinbusch, H.W., Pawluski, J.L., 2011. Fluoxetine during Development Reverses the Effects of Prenatal Stress on Depressive-Like Behavior and Hippocampal Neurogenesis in Adolescence. PLoS ONE 6. doi:10.1371/journal.pone.0024003

Reefhuis, J., Devine, O., Friedman, J.M., Louik, C., Honein, M.A., 2015. Specific SSRIs and birth defects: bayesian analysis to interpret new data in the context of previous reports. BMJ 351, h3190. doi:10.1136/bmj.h3190

Reis, M., Källén, B., 2010. Delivery outcome after maternal use of antidepressant drugs in pregnancy: an update using Swedish data. Psychol. Med. 40, 1723-1733. doi:10.1017/S0033291709992194

Retz, W., Freitag, C.M., Retz-Junginger, P., Wenzler, D., Schneider, M., Kissling, C., Thome, J., Rösler, M., 2008. A functional serotonin transporter promoter gene polymorphism increases ADHD symptoms in delinquents: Interaction with adverse childhood environment. Psychiatry Res. 158, 123-131. doi:10.1016/j.psychres.2007.05.004

Riccio, O., Jacobshagen, M., Golding, B., Vutskits, L., Jabaudon, D., Hornung, J.P., Dayer, A.G., 2011. Excess of serotonin affects neocortical pyramidal neuron migration. Transl. Psychiatry 1, e47. doi:10.1038/tp.2011.49

Rice, F., Harold, G.T., Boivin, J., van den Bree, M., Hay, D.F., Thapar, A., 2010. The links between prenatal stress and offspring development and psychopathology: disentangling environmental and inherited influences. Psychol. Med. 40, 335-345. doi:10.1017/S0033291709005911

Robertson, E., Grace, S., Wallington, T., Stewart, D.E., 2004. Antenatal risk factors for postpartum depression: a synthesis of recent literature. Gen. Hosp. Psychiatry 26, 289-295. doi:10.1016/j.genhosppsych.2004.02.006

Rodriguez, A., Bohlin, G., 2005. Are maternal smoking and stress during pregnancy related to ADHD symptoms in children? J. Child Psychol. Psychiatry 46, 246-254. doi:10.1111/j.14697610.2004.00359.x

Rodriguez-Porcel, F., Green, D., Khatri, N., Harris, S.S., May, W.L., Lin, R.C.S., Paul, I.A., 2011. Neonatal Exposure of Rats to Antidepressants Affects Behavioral Reactions to Novelty and Social Interactions in a Manner Analogous to Autistic Spectrum Disorders. Anat. Rec. Adv. Integr. Anat. Evol. Biol. 294, 1726-1735. doi:10.1002/ar.21402

Ronald, A., Pennell, C.E., Whitehouse, A.J.O., 2011. Prenatal Maternal Stress Associated with ADHD and Autistic Traits in early Childhood. Front. Psychol. 1. doi:10.3389/fpsyg.2010.00223

Rubenstein, J.L.R., 1998. Development of serotonergic neurons and their projections. Biol. Psychiatry 44, 145-150. doi:10.1016/S0006-3223(98)00133-4

Sadler, N.C., Nandhikonda, P., Webb-Robertson, B.-J., Ansong, C., Anderson, L.N., Smith, J.N., Corley, R.A., Wright, A.T., 2016. Hepatic Cytochrome P450 Activity, Abundance, and Expression 
Throughout Human Development. Drug Metab. Dispos. 44, 984-991. doi:10.1124/dmd.115.068593

Sanacora, G., Treccani, G., Popoli, M., 2012. Towards a glutamate hypothesis of depression. Neuropharmacology 62, 63-77. doi:10.1016/j.neuropharm.2011.07.036

Schain, R.J., Freedman, D.X., 1961. Studies on 5-hydroxyindole metabolism in autistic and other mentally retarded children. J. Pediatr. 58, 315-320.

Scholl, J.L., Renner, K.J., Forster, G.L., Tejani-Butt, S., 2010. Central monoamine levels differ between rat strains used in studies of depressive behavior. Brain Res. 1355, 41-51. doi:10.1016/j.brainres.2010.08.003

Semple, B.D., Blomgren, K., Gimlin, K., Ferriero, D.M., Noble-Haeusslein, L.J., 2013. Brain development in rodents and humans: Identifying benchmarks of maturation and vulnerability to injury across species. Prog. Neurobiol. 106-107, 1-16. doi:10.1016/j.pneurobio.2013.04.001

Silva, C.M. da, Gonçalves, L., Manhaes-de-Castro, R., Nogueira, M.I., 2010. Postnatal fluoxetine treatment affects the development of serotonergic neurons in rats. Neurosci. Lett. 483, 179183. doi:10.1016/j.neulet.2010.08.003

Slattery, D.A., Cryan, J.F., 2012. Using the rat forced swim test to assess antidepressant-like activity in rodents. Nat. Protoc. 7, 1009-1014. doi:10.1038/nprot.2012.044

Smit-Rigter, L.A., Noorlander, C.W., von Oerthel, L., Chameau, P., Smidt, M.P., van Hooft, J.A., 2012. Prenatal fluoxetine exposure induces life-long serotonin 5-HT3 receptor-dependent cortical abnormalities and anxiety-like behaviour. Neuropharmacology 62, 865-870. doi:10.1016/j.neuropharm.2011.09.015

Sodhi, M.S.K., Sanders-Bush, E., 2004. Serotonin and brain development. Int. Rev. Neurobiol. 59, 111-174. doi:10.1016/S0074-7742(04)59006-2

Sprowles, J.L.N., Hufgard, J.R., Gutierrez, A., Bailey, R.A., Jablonski, S.A., Williams, M.T., Vorhees, C.V., 2016. Perinatal exposure to the selective serotonin reuptake inhibitor citalopram alters spatial learning and memory, anxiety, depression, and startle in Sprague-Dawley rats. Int. J. Dev. Neurosci. 54, 39-52. doi:10.1016/j.ijdevneu.2016.08.007

Steer, R.A., Scholl, T.O., Hediger, M.L., Fischer, R.L., 1992. Self-reported depression and negative pregnancy outcomes. J. Clin. Epidemiol. 45, 1093-1099. doi:10.1016/0895-4356(92)90149-H

Sullivan, G.M., Mann, J.J., Oquendo, M.A., Lo, E.S., Cooper, T.B., Gorman, J.M., 2006. Low Cerebrospinal Fluid Transthyretin Levels in Depression: Correlations with Suicidal Ideation and Low Serotonin Function. Biol. Psychiatry 60, 500-506.

doi:10.1016/j.biopsych.2005.11.022

Sundström, E., Kölare, S., Souverbie, F., Samuelsson, E.B., Pschera, H., Lunell, N.O., Seiger, A., 1993. Neurochemical differentiation of human bulbospinal monoaminergic neurons during the first trimester. Brain Res. Dev. Brain Res. 75, 1-12.

Swerts, C.A.S., Costa, A.M.D.D., Esteves, A., Borato, C.E.S., Swerts, M.S.O., 2010. Effects of fluoxetine and imipramine in rat fetuses treated during a critical gestational period: a macro and microscopic study. Rev. Bras. Psiquiatr. Sao Paulo Braz. 1999 32, 152-158.

Talge, N.M., Neal, C., Glover, V., the Early Stress, T.R. and P.S.N.F. and N.E. on C. and A.M.H., 2007. Antenatal maternal stress and long-term effects on child neurodevelopment: how and why? J. Child Psychol. Psychiatry 48, 245-261. doi:10.1111/j.1469-7610.2006.01714.x

Törk, I., 1990. Anatomy of the Serotonergic Systema. Ann. N. Y. Acad. Sci. 600, 9-34. doi:10.1111/j.1749-6632.1990.tb16870.x

Turner, P.V., Brabb, T., Pekow, C., Vasbinder, M.A., 2011. Administration of Substances to Laboratory Animals: Routes of Administration and Factors to Consider. J. Am. Assoc. Lab. Anim. Sci. JAALAS 50, 600.

Van den Bergh, B.R.H., Marcoen, A., 2004. High antenatal maternal anxiety is related to ADHD symptoms, externalizing problems, and anxiety in 8- and 9-year-olds. Child Dev. 75, 10851097. doi:10.1111/j.1467-8624.2004.00727.x 
Varrault, A., Bockaert, J., Waeber, C., 1992. Activation of 5-HT1A receptors expressed in NIH-3T3 cells induces focus formation and potentiates EGF effect on DNA synthesis. Mol. Biol. Cell 3, 961.

Velasquez, J.C., Bonnin, A., 2016. Placental Transport and Metabolism: Implications for the Developmental Effects of Selective Serotonin Reuptake Inhibitors (SSRI) Antidepressants, in: Walker, D.W. (Ed.), Prenatal and Postnatal Determinants of Development. Springer New York, New York, NY, pp. 245-262.

Verney, C., Lebrand, C., Gaspar, P., 2002. Changing distribution of monoaminergic markers in the developing human cerebral cortex with special emphasis on the serotonin transporter. Anat. Rec. 267, 87-93. doi:10.1002/ar.10089

Vitalis, T., Parnavelas, J.G., 2003. The role of serotonin in early cortical development. Dev. Neurosci. 25, 245-256. doi:72272

Whitaker-Azmitia, P.M., 2001. Serotonin and brain development: role in human developmental diseases. Brain Res. Bull., Serotonin: From the Molecule to the Clinic 56, 479-485. doi:10.1016/S0361-9230(01)00615-3

Whitworth, T.L., Herndon, L.C., Quick, M.W., 2002. Psychostimulants Differentially Regulate Serotonin Transporter Expression in Thalamocortical Neurons. J. Neurosci. 22, RC192-RC192.

Yonkers, K.A., Wisner, K.L., Stewart, D.E., Oberlander, T.F., Dell, D.L., Stotland, N., Ramin, S., Chaudron, L., Lockwood, C., 2009. The management of depression during pregnancy: a report from the American Psychiatric Association and the American College of Obstetricians and Gynecologists. Gen. Hosp. Psychiatry 31, 403. doi:10.1016/j.genhosppsych.2009.04.003

Zhang, X., Gainetdinov, R.R., Beaulieu, J.-M., Sotnikova, T.D., Burch, L.H., Williams, R.B., Schwartz, D.A., Krishnan, K.R.R., Caron, M.G., 2005. Loss-of-Function Mutation in Tryptophan Hydroxylase-2 Identified in Unipolar Major Depression. Neuron 45, 11-16. doi:10.1016/j.neuron.2004.12.014

Zheng, J., Xu, D.-F., Li, K., Wang, H.-T., Shen, P.-C., Lin, M., Cao, X.-H., Wang, R., 2011. Neonatal exposure to fluoxetine and fluvoxamine alteres spine density in mouse hippocampal CA1 pyramidal neurons. Int. J. Clin. Exp. Pathol. 4, 162.

Zuckerman, B., Amaro, H., Bauchner, H., Cabral, H., 1989. Depressive symptoms during pregnancy: relationship to poor health behaviors. Am. J. Obstet. Gynecol. 160, 1107-1111. 